\title{
Laccases and their applications: A patent review
}

\author{
Adinarayana Kunamneni*, Francisco J. Plou, Antonio Ballesteros and Miguel \\ Alcalde
}

Departamento de Biocatálisis, Instituto de Catálisis y Petroleoquímica, CSIC, Cantoblanco, 28049 Madrid, Spain.

*Address correspondence to this author at the Departamento de Biocatálisis, Instituto de Catálisis y Petroleoquímica, CSIC, Cantoblanco, Marie Curie 2, 28049 Madrid, Spain; Tel: +34 915855479; Fax: +34 91-5854760; E-mail: adikunamneni@ rediffmail.com 
Abstract: Laccases are an interesting group of multi copper enzymes, which have received much attention of researchers in last decades due to their ability to oxidize both phenolic and non-phenolic lignin related compounds as well as highly recalcitrant environmental pollutants. This makes these biocatalysts very useful for their application in several biotechnological processes. Such applications include the detoxification of industrial effluents, mostly from the paper and pulp, textile and petrochemical industries, polymer synthesis, bioremediation of contaminated soils, wine and beverage stabilization. Laccases are also used as catalysts for the manufacture of anti-cancer drugs and even as ingredients in cosmetics. Recently, the utility of laccases has also been applied to nanobiotechnology. This paper reviews recent and important patents related to the properties, heterologous production, molecular cloning, and applications of laccases within different industrial fields as well as their potential extension to the nanobiotechnology area.

Keywords: Laccases, Properties, Heterologous production, Molecular cloning, Industrial applications of enzymes, Food industry, Nanobiotechnology, Pulp and paper industry, Textile industry, Organic synthesis, Pharmaceutical sector, Bioremediation.

Running title: A patent review on laccases 


\section{INTRODUCTION}

Laccase (EC 1.10.3.2) is a multicopper blue oxidase that couples the fourelectron reduction of oxygen with the oxidation of a broad range of organic substrates, including phenols, polyphenols, anilines, and even certain inorganic compounds by a one-electron transfer mechanism [1-4]. Laccase is widely distributed in higher plants and fungi [5] and has been found also in insects and bacteria. Recently a novel polyphenol oxidase with laccase like activity was mined from a metagenome expression library from bovine rumen microflora [6]. Since their discovery more than one century ago in the Japanese tree Rhus vernicifera [7], laccases have been found to be widely distributed among plants, where they are involved in the synthesis of lignin and in the wounding response. Lignin, which provides the structural component of the plant cell wall, is a heterogeneous and complex biopolymer that consists of phenyl propanoid units linked by various non-hydrolyzable C-C and C-O bonds [8]. For many years, it was thought that only the ligninolytic system of some white-rot fungi capable of degrading this recalcitrant polymer to a major extent involved lignin peroxidase (LiP) and manganese peroxidase (MnP) [9]. Although the latter can only oxidize the phenolic components of lignin, lignin peroxidase -which has a high redox potential- is also capable of cleaving the non-phenolic aromatic part. The main limitation of all hemecontaining peroxidases is their low operational stability, mostly due to their rapid deactivation by hydrogen peroxide. Also, the dependence of $\mathrm{Mn}^{2+}$ (for the $\mathrm{MnP}$ ) or veratryl alcohol (for the LiP) are further shortcomings for their practical application. On the other hand, laccase alone is incapable of cleaving the non-phenolic bonds of lignin, and it was not considered a significant component of the ligninolytic system, despite the secretion of large quantities of laccase by these fungi under ligninolytic conditions. However, Bourbonnais and Paice [10] reported that laccases can catalyze the oxidation 
of non-phenolic benzylalcohols in the presence of a redox mediator, such as 2,2'-azinobis-[3-ethylthiazoline-6-sulfonate] (ABTS). This finding led to the discovery that laccase-mediator systems (LMS) effectively degrade residual lignin in unbleached pulp [11]. Indeed, laccases produced by some wood-rotting fungi from the genus Basidiomycete play a major role in the biodegradation of lignin [12] and have the capability to oxidize recalcitrant aromatic compounds with redox potentials exceeding their own with the help of natural or chemical mediators $[2,13]$. Because of their wide reaction capabilities as well as the broad substrate specificity, the laccase and the LMS possess great biotechnological potential. Promising applications include textile-dye bleaching [14], pulp bleaching [15], food improvement [16], bioremediation of soils and water [17,18], polymer synthesis [19], and the development of biosensors and biofuel cells $[20,21]$.

The main aim of this work is to summarize the important patent literature data that has accumulated in the recent years about the properties, heterologous production and molecular cloning of laccases. In addition, applications of laccases within different industrial fields as well as their potential extension to the nanobiotechnology area, will also be discussed, particularly those appearing as published patents. Overall, this review is intended to discuss the laccases for biocatalysis and associated new patents.

\section{PROPERTIES OF LACCASES}

Current knowledge about the structure and physico-chemical properties of fungal proteins is based on the study of purified proteins. Up to now, more than 100 laccases have been purified from fungi and been more or less characterized. The laccase molecule, as an active holoenzyme form, is a dimeric or tetrameric glycoprotein, usually containing -per monomer- four copper $(\mathrm{Cu})$ atoms bound to three redox sites (Type 1 , Type 2 and Type $3 \mathrm{Cu}$ pair). The molecular mass of the monomer ranges from about 50 
to $100 \mathrm{kDa}$ with acidic isoelectric point around $\mathrm{pH}$ 4.0. An important feature is the high level of glycosylation (with covalently linked carbohydrate moieties ranging from 10 $50 \%$ of the total weight, depending on the species or the heterologous host), which may contribute to the high stability of the enzyme [22]. Several laccase isoenzymes have been detected in many fungal species. More than one isoenzyme is produced in most white-rot fungi.

Until recently, the three-dimensional structure of five fungal laccases has been reported: Coprinus cinereus (in a copper Type 2-depleted form) [23-26], Trametes versicolor [1,27], Pycnoporus cinnabarinus [28], Melanocarpus albomyces [29] and Rigidoporus lignosus [30], the latter four enzymes with a full complement of $\mathrm{Cu}$ ions. Moreover, the three-dimensional structure of the CoA laccase from Bacillus subtilis endospore has also recently been published [31,32].

For the catalytic activity a minimum of four $\mathrm{Cu}$ atoms per active protein unit is needed. Three types of copper can be distinguished using UV/visible and electronic paramagnetic resonance (EPR) spectroscopy. Type $1 \mathrm{Cu}$ at its oxidised resting state is responsible for the blue colour of the protein at an absorbance of approximately $610 \mathrm{~nm}$ and is EPR detectable, Type $2 \mathrm{Cu}$ does not confer colour but is EPR detectable and Type $3 \mathrm{Cu}$ atoms consists of a pair of $\mathrm{Cu}$ atoms in a binuclear conformation that give a weak absorbance in the near UV region but no detectable EPR signal [33]. The Type 2 and Type 3 copper sites are close together and form a trinuclear centre that are involved in the catalytic mechanism of the enzyme [33].

The redox potential of the Type 1 site has been determined for many laccases using different mediators and varies from $430 \mathrm{mV}$ for the laccase from $R$. vernicifera tree up to $780 \mathrm{mV}$ for fungal laccase from Polyporus versicolor [3,24,34]. It was previously found that the catalytic efficiency $\left(k_{c a t} / K_{m}\right)$ of laccases for some reducing 
substrates depended linearly on the redox potential of the Type 1 copper, in the sense that the higher the potential of the Type 1 site the higher the catalytic efficiency [3]. That is why laccases with a high redox potential of the Type 1 site are of special interest in biotechnology, e.g., for efficient bleaching and bioremediation processes.

\section{Catalysis by laccase}

To function, laccase depends on $\mathrm{Cu}$ atoms distributed among the three different binding sites. $\mathrm{Cu}$ atoms play an essential role in the catalytic mechanism. There are three major steps in laccase catalysis. The Type $1 \mathrm{Cu}$ is reduced by a reducing substrate, which therefore is oxidized. The electron is then transferred internally from Type $1 \mathrm{Cu}$ to a trinuclear cluster made up of the Type 2 and Type $3 \mathrm{Cu}$ atoms (Fig. 1). The $\mathrm{O}_{2}$ molecule is reduced to water at the trinuclear cluster.

\section{Place for Fig. 1}

The $\mathrm{O}_{2}$ molecule binds to the trinuclear cluster for asymmetric activation and it is postulated that the $\mathrm{O}_{2}$ binding pocket appears to restrict the access of oxidizing agents other than $\mathrm{O}_{2} \cdot \mathrm{H}_{2} \mathrm{O}_{2}$ is not detected outside of laccase during steady state laccase catalysis indicating that a four electron reduction of $\mathrm{O}_{2}$ to water is occurring [34]. A one-electron substrate oxidation is coupled to a four-electron reduction of oxygen so the reaction mechanism cannot be straightforward. Laccase must operate as a battery, storing electrons from individual substrate oxidation reaction to reduce molecular oxygen. In fact, it appears that bound oxygen intermediates are also involved [34]. Details of the $\mathrm{O}_{2}$ reduction have not been fully elucidated and continue to be studied.

From a mechanistic point of view, the reactions catalyzed by laccases for bioremediatory and biotechnological applications can be represented by one of the schemes shown in Fig. 2. The simplest case (Fig. 2a) is the one in which the substrate 
molecules are oxidized to the corresponding radicals by direct interaction with the copper cluster. Laccases use oxygen as the electron acceptor to remove protons from the phenolic hydroxyl groups. This reaction gives rise to radicals that can spontaneously rearrange, which can lead to fission of $\mathrm{C}-\mathrm{C}$ or $\mathrm{C}-\mathrm{O}$ bonds of the alkyl side chains, or to cleavage of aromatic rings.

Frequently, however, the substrates of interest cannot be oxidized directly by laccases, either because they are too large to penetrate into the enzyme active site or because they have a particularly high redox potential. By mimicking nature, it is possible to overcome this limitation with the addition of so-called 'chemical mediators', which are suitable compounds that act as intermediate substrates for the laccase, whose oxidized radical forms are able to interact with the bulky or high redox-potential substrate targets (Fig. 2b).

\section{Place for Fig. 2}

\section{Laccase mediator system (LMS)}

Biobleaching techniques have been intensively investigated as a possible alternative for chlorine bleaching of pulp. It is known that white-rot fungi are able to perform lignin degradation using a cocktail of oxidative enzymes, including laccases, despite the fact that the bulkiness of this polymer prevents direct interaction with these enzymes. Indeed, it has been shown that the treatment of pulp with laccase alone does not catalyze the degradation of lignin but instead leads to only minor structural changes and repolymerization [35]. It has been hypothesized that small redox molecules might act as a sort of "electron shuttles" between the enzyme and the lignin and cause polymer debranching and degradation [36]. Nowadays, this is regarded as more than just a hypothesis because the effect of chemical mediators, such as 3-hydroxyanthranilic acid 
(HAA, Fig. 3a), on laccase-catalyzed lignin degradation has been evaluated extensively [36]. The first artificial mediator that was used in the LMS for pulp delignification is ABTS (Fig. 3b), which was introduced by Bourbonnais and Paice in 1990 [10]. Since then, over 100 possible mediator compounds have been tested for their ability to oxidize lignin or lignin models through the selective oxidation of their benzylic hydroxyl groups [37], and the most suitable ones are illustrated in Fig. 3. The most effective mediators for lignin degradation proved to be the $N$-heterocycles bearing $N-\mathrm{OH}$ groups (Fig. 3c-g) and in particular HBT ( $N$-hydroxybenzotriazole; Fig. 3c). The process has been patented under the trade name 'Lignozym ${ }^{\circledR}$ process', and its efficiency has been demonstrated in several pilot plant trials [37]. The evaluation of the performance of 12 different mediators in the oxidation of 4-methoxybenzyl alcohol, used as a model substrate, showed that TEMPO (2,2,6,6-tetramethylpiperidine-1-oxyl; Fig. 3h) was the most effective compound for this kind of reaction [37]. A number of synthetic organic and inorganic mediators have been patented [36,38], and naturally occurring "native" mediators for laccases have been discovered and identified [39]. Moreover, the natural phenolic substrates of laccases, which are part of the extractive substances of wood, could also be the enhancers for the enzyme and increase the activity of laccase towards the lignin matrix during its destruction by fungi [40].

\section{Place for Fig. 3}

The LMS concept was successfully applied to the oxidation of aromatic methyl groups, benzyl alcohols [41], polycyclic aromatic hydrocarbons (PAHs) [18,41] and bleaching of textile dyes [14]. However, despite that the addition of mediators may broaden the applicability of laccase, there are two major drawbacks hindering their use, they are expensive and are often toxic [41]. 
Various PAHs, which closely correlate to the 16 compounds selected by the Environmental Protection Agency (USA) and other national institutions as compounds of toxicological relevance were removed by a LMS. PAHs that were removed included acenaphtylene, anthracene, benzo(a)pyrene, acenaphthene, fluoranthene, pyrene, benzo(a)anthracene, chrysene, benzo(b)fluoranthene, benzo(k)fluoranthene and perylene [41]. PAH quinones were formed to differing degrees as oxidation products.

The activity of a LMS towards lignin is dependant on two main factors: firstly, the redox potential of the enzyme and, secondly, the stability and reactivity of the radical are resulting from the oxidation of the mediator. It has been shown that laccases from different organisms react variably with different mediators and different substrates [10]. It is thus imperative that different laccases as well as different mediator compounds be investigated.

Laccases of various origins differ in their substrate specificities and several substrates should be tested to assess a laccase activity. A very wide range of substrates has been shown to be oxidized by laccases (Table 1) but the catalytic constants have been reported mostly for a small group of substrates- e.g. the non-natural test substrate ABTS and the phenolic compounds 2,6-dimethoxyphenol (2,6-DMP), guaiacol and syringaldazine. These constants have been measured for a large number of laccases, and rather great variation can be observed among them (Table 1). The $K_{m}$ values of laccases are in the range of $2-5000 \mu \mathrm{M}$, but differences as high as 3500 -fold can be seen in the $k_{c a t}$ values between different laccases with the same substrates (Table 1). The $K_{m}$ values measured for 2,6-DMP are generally higher than those obtained with syringaldazine. The comparison of $K_{m}$ values also shows that laccases from different source organisms have different substrate preferences [3]. Laccases in general combine high affinity for ABTS and syringaldazine with high catalytic constant, whereas the oxidation of 
guaiacol and DMP is considerably slower and the respective $K_{m}$ constants higher. On the other hand, the $k_{c a t}$ values for a single laccase do not generally differ more than 210-fold between different substrates, which reflects the fact that the $k_{c a t}$ describes the rate of the electron-transfer reactions taking place inside the enzyme after substrate binding [3]. This can be seen, for example, for laccases from Pleurotus sajor-caju, Trametes pubescens and Trametes trogii in Table 1. However, the variance in assay conditions must always be taken into account when the catalytic constants measured in different laboratories are compared. The constants in Table 1 have been measured in varying $\mathrm{pH}$, ionic strength and temperature conditions and using different protein concentrations, all of which have a great effect on the results. In addition, different molar extinction coefficients for oxidation products have sometimes been used in spectrophotometric assays, because the nature of the actual oxidation products is often complex or poorly understood. This affects particularly the numerical values of $k_{\text {cat }}$.

\section{Place for Table 1}

Anions such as the halides, azide, cyanide and hydroxide bind to the Type 2 and $3 \mathrm{Cu}$ atoms of laccases, which disrupts the electron transfer system, resulting in enzyme inhibition $[34,42,43]$. The inhibition by hydroxide generally prevents catalysis of substrates at alkaline $\mathrm{pH}$ [2]. The inhibition of activity by hydroxide prevents autoxidation at alkaline $\mathrm{pH}$, with a resultant increase in stability at alkaline $\mathrm{pH}$ [2]. The inhibition by halides varies according to the laccase isozyme, and therefore likely related to the size of the channel of the trinuclear cluster (where oxygen binds) [2].

Other types of inhibitors include certain metal ions (e.g. $\mathrm{Hg}^{2+}$ ), fatty acids, sulfhydril reagents, hydroxyglycine, kojic acid, and cationic quaternary ammonium detergents 
[34]. These compounds may affect the laccase by chelating the $\mathrm{Cu}$ (II) atoms, by modifying of amino acid residues or they may elicit a conformational change in the glycoprotein.

\section{HETEROLOGOUS PRODUCTION OF LACCASES}

In most fungi, laccases are produced in the native hosts at levels that are too low for commercial purposes. Therefore, improving the productivity and reducing the production cost are the major goals for the current studies on laccase production. Cloning of the laccase genes followed by heterologous expression may provide higher enzyme yields.

In order to improve laccase production, fungal laccases have been expressed heterologously in Saccharomyces cerevisiae [48,49,60-63], Trichoderma reesei [48,54,64], Aspergillus oryzae [65-71], Pichia pastoris [51,72-76], Yarrowia lipolitica [77], Aspergillus sojae [78], Aspergillus niger [52,79], Aspergillus nidulans [69,79,80], Aspergillus ficuum [81], tobacco [82-85] and maize [86-88]. Bacterial laccases from $B$. subtilis, Thermus thermophilus and Streptomyces lavendulae have been expressed in Escherichia coli $[44,89-91]$ but successful expression of fungal laccases in E. coli has not been reported.

In spite of the fact that laccase production levels have often been improved significantly by expression in heterologous hosts, the reported levels are still rather low for industrial applications (Table 2). Improved laccase production levels have also been achieved by expression in $P$. pastoris, whereas expression in S. cerevisiae has generally resulted in very low activity levels [92]. Recently, successful use of $S$. cerevisiae expressing $M$. thermophila laccase by directed evolution was reported by Bulter et al., who obtained very promising results [49]. The addition of copper into the culture medium also proved to be important for heterologous laccase 
production in $P$. pastoris and Aspergillus spp. $[75,79,93]$. The importance of adequate copper concentration for proper laccase folding was further corroborated by studies in which two genes related to copper-trafficking in $T$. versicolor were overexpressed in $S$. cerevisiae expressing T. versicolor lacIII gene: the heterologous laccase production by S. cerevisiae was improved up to 20 -fold $[94,95]$. The effect was suggested to result from more efficient transport of copper to the Golgi compartment [94,95]. Also, the improved laccase production levels have been obtained in heterologous production systems in a laboratory-scale fermentor cultivation by expression of $M$. albomyces in $T$. reesei, which yielded $920 \mathrm{mg}$ laccase per liter [63]. Recently, an efficient transformation and expression system was developed for the basidiomycete $P$. cinnabarinus and this was used to transform a laccase-deficient monokaryotic strain with the homologous lacl laccase gene. The yield obtained was as high as $1200 \mathrm{mg} \mathrm{l}^{-1}$ and represents the highest laccase production reported for recombinant fungal strains $[96,97]$. It has not been established whether production levels in a strain that already produces such high levels of laccase can be further increased by genetic modification.

\section{Place for Table 2}

\section{cDNA AND GENE SEQUENCES}

The first gene and/or cDNA sequences were recorded for laccase from the Ascomycete fungus, Neurospora crassa [98], and sequences were published from 1990 onwards. These included laccases from A. nidulans [99], Coriolus hirsutus [60,62], Phlebia radiata [100], Agaricus bisporus [101], P. cinnabarinus [102], Coriolus versicolor [103], T. versicolor [72], Podospora anserina [104], Coprinus congregatus [105], Ganoderma lucidum, Phlebia brevispora, Lentinula edodes and Lentinus tigrinus 
$[42,106]$. Since then, the number of laccase genes sequenced has increased considerably, and searches from protein and gene sequence databases currently yield several hundreds of laccase gene sequences. However, a significant number of these are only partial stretches of putative laccase genes that have been found in genome-wide sequencing projects and have been annotated on the basis of sequence homology with known laccases. The number of laccase genes of which the corresponding protein products have been experimentally characterized is significantly lower. To date, there are about 21 such enzymes, most of which are fungal laccases (Table 3). In addition to the genes shown in Table 3, several laccase genes have been characterized in detail at the nucleotide level but have not been specified to code for a known laccase protein.

The sequences mostly encode polypeptides of approximately 500 to 600 amino acids (including the N-terminal secretion peptide) (Table 3). All the laccases listed in Table 3 are secreted proteins, and typical eukaryotic signal peptide sequences of about 21 amino acids are found at the $\mathrm{N}$-termini of the protein sequences. In addition to the secretion signal sequence, laccase genes from $N$. crassa, $P$. anserina, M. thermophila and C. cinereus contain regions that code for N-terminal cleavable propeptides $[66,69,104,107]$. These laccases also have C-terminal extensions of controversial function, i.e. the last amino acids from the predicted amino acid sequence are not present in the mature protein $[66,69,107]$.

The one cysteine and ten histidine residues involved in the binding of copper atoms were conserved for laccases and this is also similar to what is found for sequences from ascorbate oxidase. The difference between laccases and ascorbate oxidases in the copper-binding region is that the latter exhibits the presence of a methionine axial ligand, which is not present in the laccase sequences. The 
absence/presence of the methionine ligand has led to interesting studies of mutagenesis conducted by Xu and coworkers $[108,109]$.

Place for Table 3

\section{APPLICATIONS OF LACCASES}

A few laccases are at present in market for textile, food and other industries, and more candidates are being actively developed for future commercialization. A vast amount of industrial applications for laccases have been proposed and they include pulp and paper, textile, organic synthesis, environmental, food, pharmaceuticals and nanobiotechnology. Being specific, energy-saving, and biodegradable, laccase-based biocatalysts fit well with the development of highly efficient, sustainable, and ecofriendly industries.

\section{PULP AND PAPER INDUSTRY}

In the industrial preparation of paper the separation and degradation of lignin in wood pulp are conventionally obtained using chlorine- or oxygen-based chemical oxidants. Non-chlorine bleaching of pulp with laccase was first patented in 1994 using an enzyme treatment to obtain a brighter pulp with low lignin content [119]. Oxygen delignification process has been industrially introduced in the last years to replace conventional and polluting chlorine-based methods. In spite of this new method, the pre-treatments of wood pulp with laccase can provide milder and cleaner strategies of delignification that also respect the integrity of cellulose [120-123]. Laccases are able to delignify pulp when they are used together with mediators [124]. Small natural lowmolecular weight compounds with high redox potential $(>900 \mathrm{mV})$ called mediators may be used to oxidize the non-phenolic residues from the oxygen delignification [124]. 
The mediator is oxidized by laccase and the oxidized mediator molecule further oxidizes subunits of lignin that otherwise would not be laccase substrates $[10,125]$. Although the LMS has been studied extensively, there are still unresolved problems concerning with mediator recycling, cost and toxicity. However, some environmental benefits are envisaged and the fact that LMS could be easily implemented in the existing bleaching sequences is seen as a major advantage that could possibly lead to a partial replacement of $\mathrm{ClO}_{2}$ in pulp mills. Furthermore, the application of laccases in pulp-kraft bleaching may result in higher pulp yields and energy savings. Most of studies have been patented about the use of LMS in the pulp-kraft bleaching processes [123,126-141]. More recently, the potential of this enzyme for cross-linking and functionalizing ligninaceous compounds was discovered [142-145]. In another related application, laccases can be even used for deinking and decolorizing a printed paper [146-149]. Finally, laccases can be used for binding fiber-, particle- and paper-boards [143,150-153]. However, different wood-decaying basidiomycetes have shown a highly variable pattern of laccase formation, and this subject requires more detailed experiments [154].

\section{TEXTILE INDUSTRY}

Laccase is used in commercial textile applications to improve the whiteness in conventional bleaching of cotton and recently biostoning [155-157]. Potential benefits of the application include chemicals, energy, and water saving. Cellulases were used to partially replace the load of pumice stones and laccases could bleach indigo-dyed denim fabrics to lighter shades [158-163]. Laccase also can be used in situ to convert dye precursors for better, more efficient fabric dyeing [160,164-166]. In the last few years, various patents reported on coloration achieved with laccase [164,167-173]. 
Laccases find potential applications for cleansing, such as cloth- and dishwashing [174-176]. Laccase may be included in a cleansing formulation to eliminate the odor on fabrics, including cloth, sofa surface, and curtain, or in a detergent to eliminate the odor generated during cloth washing [70,177-179]. A patent application about the use of LMS to increase the shrink resistance of wool was published [180]. Also, Lantto et al. [181] found that wool fibers can be activated with LMS. Therefore, the use of laccase for anti-shrink treatment of wool seems very attractive.

\section{FOOD INDUSTRY}

Many laccase substrates, such as carbohydrates, unsaturated fatty acids, phenols, and thiol-containing proteins, are important components of various foods and beverages. Their modification by laccase may lead to new functionality, quality improvement, or cost reduction $[16,174]$. Sometimes $\mathrm{O}_{2}$ is detrimental to the quality or storage of food/beverage because of unwanted oxidation. Laccases may be used as $\mathrm{O}_{2-}$ scavengers for better food packing [182].

The flavor quality of vegetable oils can be improved with laccase by eliminating dissolved oxygen [183]. Laccase can also deoxygenate food items derived partly or entirely from extracts of plant materials. Cacao was soaked in solutions containing laccase, dried and roasted in order to improve the flavor and taste of cacao and its products $[184,185]$. The reduction of odors with laccase is documented in the patent literature $[186,187]$. Treatment with a fungal laccase can also be performed to enhance the color of a tea-based product [81,188-190]. It is also used to perform the cross-link of ferulic acid and sugar beet pectin through oxidative coupling to form gels for food ingredients $[60,191]$. Various enzymatic treatments have been proposed for fruit juice stabilization, among which it can be found the use of laccase $[16,192,193]$. Laccases are added to the dough used for producing baked products, to exert an oxidizing effect on 
the dough constituents and to improve the strength of gluten structures in dough and/or baked products $[16,81,194]$.

Wine stabilization is one of the main applications of laccase in the food industry as alternative to physical-chemical adsorbents [16,195-198]. Musts and wines are complex mixtures of different chemical compounds, such as ethanol, organic acids (aroma), salts and phenolic compounds (color and taste). Polyphenol removal must be selective to avoid an undesirable alteration in the wine's organoleptic characteristics. Laccase presents some important requirements when used for the treatment of polyphenol elimination in wines, such as stability in acid medium and reversible inhibition with sulphite [199]. Laccases are also used to improve storage life of beer. Haze formation in beers is a persistent problem in the brewing industry. Nucleophilic substitution of phenolic rings by protein sulphydryl groups may lead to a permanent haze that does not re-dissolve when warmed. As an alternative to the traditional treatment to remove the excess of polyphenols, laccase could be added to the wort $[16,200]$. Other studies of laccase application for phenolic compounds removal have also been patented [185,201]. A laccase has recently been commercialized $\left(\right.$ Suberzyme $\left.^{\circledR}\right)$ for preparing cork stoppers for wine bottles [202].

\section{BIOREMEDIATION}

Laccases have many possible applications in bioremediation [159]. Laccases may be applied to degrade various substances such as undesirable contaminants, byproducts, or discarded materials. Laccase may be applied to degrade plastic waste having olefin units $[203,204]$. Likely, an oxidation of the olefin units by the LMS, could initiate a radical chain reaction, leading to the disintegration of the plastic. Also this LMS can be used to degrade polyurethanes [205]. LMS facilitated the degradation of phenolic compounds (environmental hormones) from biphenol and alkylphenol 
derivatives [206,207] and also the decomposition of fluorescent brighteners [208,209]. Laccase may also be used to eliminate odor emitted from places such as garbage disposal sites, livestock farms, or pulp mills [177,210]. Also, they could be used for decolorizing dye house effluents that are hardly decolorized by conventional sewage treatment plants [42,211-213]. In addition to dye house effluents, laccases can decolorize waste waters from olive oil mills [214] and pulp mills [215,216] by removing colored phenolic compounds.

Another potential environmental application for laccases is the bioremediation of contaminated soils, as laccases and LMS are able to oxidize toxic organic pollutants, such as various xenobiotics, PAHs, chlorophenols, and other contaminants $[16,89,130,177,210,218-226]$. Phenolic compounds are present in wastes from several industrial processes, as coal conversion, petroleum refining, production of organic chemicals and olive oil production among others [227,228]. Immobilized laccase was found to be useful to remove phenolic and chlorinated phenolic pollutants $[129,229$ 233]. Laccase was found to be responsible for the transformation of 2,4,6trichlorophenol to 2,6-dichloro-1,4-hydroquinol and 2,6-dichloro-1,4-benzoquinone [88,234]. LMSs have been also used to oxidize alkenes, carbazole, N-ethylcarbazole, fluorene, and dibenzothiophene [235,236]. Isoxaflutole is an herbicide activated in soils and plants to its diketonitrile derivative, the active form of the herbicide: laccases are able to convert the diketonitrile into the acid [237]. Laccase can be also used to reduce the concentration of synthetic heterocyclic compound such as halogenated organic pesticides in the soil [218]. LMS has been extensively study in the oxidation of recalcitrant PAHs, main components of several ship spills. In this sense, LMS is being included in several enzymatic bioremediation programs [238]. 


\section{ORGANIC SYNTHESIS}

Recently, increasing interest has been focused on the application of laccase as a new biocatalyst in organic synthesis [154,239]. Laccase provided an environmentally benign process of polymer production in air without the use of $\mathrm{H}_{2} \mathrm{O}_{2}$ [240,241]. Laccase-catalyzed cross-linking reaction of new urushiol analogues for the preparation of "artificial urushi” polymeric films (Japanese traditional coating) was demonstrated [242]. It is also mentioned that laccase induced radical polymerization of acrylamide with or without mediator [243,244]. Laccases are also known to polymerize various amino and phenolic compounds [245-248]. Recently, to improve the production of fuel ethanol from renewable raw materials, laccase from $T$. versicolor was expressed in $S$. cerevisiae to increase its resistance to (phenolic) fermentation inhibitors in lignocellulose hydrolyzates [92]. The preparation of crosslinked enzyme aggregrates with aldehydes and amines had improved stability and was used in starch oxidation [249]. Selective oxidation of the primary hydroxyl groups of sugars using the LMS is described in patent literature dealing with the partial oxidation of cellulose and other polysaccharides [250-254]. Also, LMS was used for the determination of monoclonal antibody of azelaic acid from oleic acid [255]. The enzymatic preparation of polymeric polyphenols by the action of laccases has been investigated extensively in the past decades as a viable and non-toxic alternative to the usual formaldehyde-based chemical production of these compounds [256-260].

Laccase can also be used to synthesize various functional organic compounds including polymers with specific mechanical/electrical/optical properties, textile dyes, cosmetic pigments, flavor agents, and pesticides [110,261-263]. 


\section{PHARMACEUTICAL SECTOR}

Many products generated by laccases are antimicrobial, detoxifying, or active personal-care agents. Due to their specificity and bio-based nature, potential applications of laccases in the field are attracting active research efforts. Laccase can be used in the synthesis of complex medical compounds as anesthetics, anti-inflammatory, antibiotics, sedatives, etc. [264-267], including triazolo(benzo)cycloalkyl thiadiazines, vinblastine, mitomycin, penicillin $\mathrm{X}$ dimer, cephalosporins, and dimerized vindoline $[159,268,269]$.

One potential application is laccase-based in situ generation of iodine, a reagent widely used as disinfectant $[159,270,271]$. Also, laccase has been reported to possess significant HIV-1 reverse transcriptase inhibitory activity [272]. Another laccase has been shown capable of fighting aceruloplasminemia (a medical condition of lacking ceruloplasmin, a multi-Cu serum oxidase whose ferroxidase activity regulates iron homeostasis) [273]. Some years ago, a new enzymatic method based on laccase was developed to distinguish simultaneously morphine and codeine in drug samples injected into a flow detection system [274].

A novel application field for laccases is in cosmetics. For example, laccasebased hair dyes could be less irritant and easier to handle than current hair dyes [159,275-289]. More recently, cosmetic and dermatological preparations containing proteins for skin lightening have also been developed [261,288,290-292]. Laccases may find use as deodorants for personal-hygiene products, including toothpaste, mouthwash, detergent, soap, and diapers [177,293-300]. Protein engineered laccase may be used to reduce allergenicity [301]. 


\section{NANOBIOTECHNOLOGY}

Nanoscience has grown rapidly in the last decade. Recently, more attention is focused on the applications of nanotechnologies. The high potential impacts of nanotechnology almost cover all fields of human activity (environmental, economy, industrial, clinical, health-related, etc). Nanostructured materials (nanoparticles, nanotubes, and nanofibers) have been used extensively as carrying materials for biosensoring, and biofuel cells.

A biosensor is an integrated biological-component probe with an electronic transducer, thereby converting a biochemical signal into a quantifiable electrical response that detects, transmits and records information regarding a physiological or biochemical change [302]. Some of the major attributes of a good biosensing system are its specificity, sensitivity, reliability, portability, real-time analysis and operation simplicity [302]. Thus laccases can be applied as biosensors or bioreporters. A number of biosensors containing laccase have been developed for immunoassays, and for determination of glucose, aromatic amines and phenolic compounds [159,274,303-308]. Laccase catalysis can be used to assay other enzymes [159,309-311]. Laccase covalently conjugated to a bio-binding molecule can be used as a reporter for immunochemical (ELISA, Western blotting), histochemical, cytochemical, or nucleic acid-detection assays $[80,159,312,313]$. The bioreporter applications are of interest for the high-sensitivity diagnostic field.

In addition to biosensors, laccases could be immobilized on the cathode of biofuel cells that could provide power, for example, for small transmitter systems [314317]. Fuel cells are very attractive energy sources, particularly at micro-, mini-, portable-, or mobile-scale, that potentially have higher energy conversion/usage efficiency and lower pollution effect than any of the existing/emerging energy sources. 
For example, a bio-implantable electrochemical cell system for active implantable medical devices is described by Choi [318]. In one embodiment, the fuel cell includes an electrode structure consisting of immobilized anode and cathode enzymes deposited on nanostructured high-surface-area metal nanowires or carbon nanotube electrodes (Fig. 4). The anode enzyme comprises immobilized glucose oxidase and the cathode enzyme comprises immobilized laccase. Glucose is oxidized at the surface of the anode and oxygen is reduced at the surface of the cathode. The coupled glucose oxidation/oxygen reduction reactions provide a self-generating current source. In another embodiment, the nanowires or carbon nanotubes, along with the adjacent surface anode and cathode electrodes, are coated with immobilized glucose oxidase and immobilized laccase containing biocolloidal substrates, respectively. This results in the precise construction of enzyme architecture with control at the molecular level, while increasing the reactive surface area and corresponding output power by at least two orders of magnitude.

\section{Place for Fig. 4}

Laccase may be applied as a biocatalyst for the electrode reactions [319-324]. Laccase-based miniature biological fuel cell is of particular interest for many medical applications calling for a power source implanted in a human body [325].

\section{POTENTIAL NEW LACCASE-BASED BIOCATALYSTS}

Enzymatic catalysis in organic solvents has opened a new field of biotechnological applications of enzymes. The ability to use enzymes in nonaqueous solvents greatly expands the potential scope and economic impact of biocatalysis. When biological catalysts are placed in this unnatural environment they exhibit a number of remarkable novel properties such as altered stereo-selectivity, enhanced stability and 
increased rigidity [326]. There is also facilitated recovery of products and biocatalyst [327]. As well in the presence of organic solvents there is less risk of microbial contamination [328]. In the specific case of laccases or LMS, many of their non-natural substrate are hardly soluble in water (their $\mathrm{Km}$ values are far away from their solubility in aqueous media), and therefore the use of cosolvents is an indispensable requirement. However, the laccase may be denatured or it may be inhibited under these conditions $[329,330]$. In this regard laccases can be applied in nonaqueous solution or multiphasic systems. For water-immiscible organic solvents, laccase may be entrapped in reverse micelles or immobilized onto a carrier [22,159,232,331]. Preferably, the reverse micelles are used in the presence of laccase mediators to enhance and mediate the laccase activity in organic solvents. Solid phase enzyme kinetics screening in microcolonies provide higher throughput, better solvent resistance and easy of handling [332]. In a recent investigation directed molecular evolution of laccases was carried out for organic cosolvents resistance [333]. The $M$. thermophila laccase expressed in $S$. cerevisiae was engineered by in vitro evolution in the presence of increasing concentrations of acetonitrile and ethanol. The turnover rates of mutant enzymes at high concentrations of organic solvents were several fold improved (our laboratory has already perfomed new cycles of in vitro evolution, achieving high activities at solvent concentrations as high as $50 \%(\mathrm{v} / \mathrm{v})$ (unpublished material).

\section{CURRENT AND FUTURE DEVELOPMENTS}

This review summarizes the available recent and important patents about the properties, heterologous production, and molecular cloning of fungal laccases and possible industrial and biotechnological use.

Laccases are promising enzymes to replace the conventional chemical processes

of several industries such as the pulp and paper, textile, pharmaceutical, and 
nanobiotechnology. However, one of the problems to commercialise the use of laccase is the lack of sufficient enzyme stocks. Thus, efforts have to be made in order to achieve cheap overproduction of laccase in heterologous hosts, and also their modification by chemical means or protein engineering, to obtain more robust, active and less expensive enzymes. Another additional problem is the cost and toxicity of redox mediators. Further investigations should consider different and less polluting mediators such as the natural mediators produced by laccase in a bio-environment during lignin degradation [13]. The current development in laccase catalysis research and the design of mediators along with the research on its heterologous expression opens a wide spectrum of possible applications in the near future. Moreover, laccase can also offer a simple and convenient alternative to using peroxidases with $\mathrm{H}_{2} \mathrm{O}_{2}$, because laccases are available on an economically feasible scale.

\section{ABBREVIATIONS}

$\begin{array}{ll}\text { LiP } & =\text { Lignin peroxidase } \\ \text { MnP } & =\text { Manganese peroxidase } \\ \text { ABTS } & =2,2 \text {-azino-bis-[3-ethylthiazoline-6-sulfonate] } \\ \text { LMS } & =\text { Laccase-mediator system } \\ \text { Cu } & =\text { Electronic paramagnetic resonance } \\ \text { EPR } & =N \text {-hydroxybenzotriazole } \\ \text { HAA } & =2,2,6,6 \text {-tetramethylpiperidine-1-oxyl } \\ \text { HBT } & =2,6 \text {-Dimethoxyphenol } \\ \text { TEMPO } & =N \text {-hydroxyacetanilide } \\ 2,6-D M P & \text { NHA }\end{array}$


VLA $\quad=$ Violuric acid

$\mathrm{PAH}=$ Polycyclic aromatic hydrocarbon

\section{ACKNOWLEDGMENTS}

This work was funded by Spanish MEC (projects VEM2004-08559 and CTQ200508925-C02-02/PPQ); EU (project NMP2-CT-2006-026456); CSIC (project 200580M121), and Ramon y Cajal Program. EU is also thanked for the Marie Curie Incoming International Fellowship within the $6^{\text {th }}$ ECFP to Dr. A. Kunamneni.

\section{REFERENCES}

[1] Piontek K, Antorini M, Choinowski T. Crystal structure of a laccase from the fungus Trametes versicolor at 1.90 - $\AA$ resolution containing a full complement of coppers. J Biol Chem 2002; 277: 37663-37669.

[2] $\mathrm{Xu}$ F. Oxidation of phenols, anilines, and benzenethiols by fungal laccases: correlation between activity and redox potentials as well as halide inhibition. Biochem 1996; 35: 7608-7614.

[3] Xu F, Shin W, Brown S, Wahleithner JA, Sundaram UM, Solomon EI. A study of a series of recombinant fungal laccases and bilirubin oxidase that exhibit significant differences in redox potential, substrate specificity, and stability. Biochim Biophys Acta 1996; 1292: 303-311.

[4] Sakurai T. Anaerobic reactions of Rhus vernicifera laccase and its type-2 copper-depleted derivatives with hexacyanoferrate(II). Biochem J 1992; 284: 681-685.

[5] Messerschmidt A, Huber R. The blue oxidases, ascorbate oxidase, laccase and ceruloplasmin, modeling and structural relationships. Eur J Biochem 1990; 187: 341-352.

[6] Beloqui A, Pita M, Polaina J, Martinez-Arias A, Golyshina OV, Zumarraga M, Yakimov MM, Garcia-Arellano H, Alcalde M, Fernandez VM, Elborough K, Andreu JM, Ballesteros A, Plou FJ, Timmis KN, Ferrer M, Golyshin PN. Novel polyphenol oxidase mined from a metagenome expression library of bovine rumen-Biochemical properties, structural analysis, and phylogenetic relationships. J Biol Chem 2006; 281: 22933-22942.

[7] Yoshida H. Chemistry of lacquer (Urushi), part I. J Chem Soc 1883; 43: 472486.

[8] Gellerstedt G, Northy RA. Analysis of birch wood lignin by oxidative degradation. Wood Sci Technol 1989; 23: 75-83.

[9] Evans CS. Laccase activity in lignin degradation by Coriolus versicolor in vivo and in vitro studies. FEMS Microbiol Lett 1985; 27: 339-343.

[10] Bourbonnais R, Paice MG. Oxidation of non-phenolic substrates: An expanded role for laccase in lignin biodegradation. FEBS Lett 1990; 267: 99-102. 
[11] Call, H.P.: WO 9429510 (1994).

[12] Coll PM, Fernandez-Abalos JM, Villanueva JR, Santamaria R, Perez P. Purification and characterization of a phenoloxidase (laccase) from the lignindegrading basidiomycete PM1 (CECT 2971). Appl Environ Microbiol 1993; 59: 2607-2613.

[13] Camarero S, Ibarra D, Martinez MJ, Martinez AT. Lignin-derived compounds as efficient laccase mediators for decolorization of different types of recalcitrant dyes. Appl Environ Microbiol 2005; 71: 1775-1784.

[14] Kierulff JV. Denim bleaching. Textile Horiz 1997; 17: 33-36.

[15] Palonen H, Viikari L. Role of oxidative enzymatic treatments on enzymatic hydrolysis of softwood. Biotechnol Bioeng 2004; 86:550-557.

[16] Minussi RC, Pastore GM, Duran N. Potential applications of laccase in the food industry. Trends Food Sci Technol 2002; 13: 205-216.

[17] Li K, Xu F, Eriksson, K-HL. (1999). Comparison of fungal laccases and redox mediators in oxidation of a nonphenolic lignin model compound. Appl Environ Microbiol 1999; 65: 2654-2660.

[18] Wesenberg D, Kyriakides I, Agathos SN. White-rot fungi and their enzymes for the treatment of industrial dye effluents. Biotechnol Adv 2003; 22: 161-187.

[19] Marzoorati M, Danieli B, Haltrich D, Riva S. Selective laccase-mediated oxidation of sugars derivatives. Green Chem 2005; 7: 310-315.

[20] Trudeau F, Diagle F, Leech D. Reagentless mediated laccase electrode for the detection of enzyme modulators. Anal Chem 1997; 69: 882-886.

[21] Tayhas G, Palmore R, Kim H-H. Electro-enzymatic reduction of dioxygen to water in the cathode compartment of a biofuel cell. J Electroanal Chem 1999; 565: 110-117.

[22] Duran N, Rosa MA, D’Annibale A, Gianfreda L. Applications of laccases and tyrosinases (phenoloxidases) immobilized on different supports: a review. Enz Microb Technol 2002; 31: 907-931.

[23] Ducros V, Brzozowski A.M., Wilson K.S., Brown S.H., Ostergaard P, Schneider P, Yaver D.S., Pedersen A.H., Davies G.J. Crystal structure of the type-2 Cu depleted laccase from Coprinus cinereus at 2.2 angstrom resolution. Nat Struct Biol 1998; 5: 310-316.

[24] Schneider, P., Danielsen, S., Svendsen, A.: WO2001083761 A1 (2001).

[25] Svendsen, A., Xu, F.: US 6184015 (2001).

[26] Roggen, E.L., Ernst, S., Svendsen, A., Friis, E.P., Von, D.O.C.: US2002192792 (2003).

[27] Bertrand T, Jolivalt C, Briozzo P, Caminade E, Joly N, Madzak C, Mougin C. Crystal structure of a four-copper laccase complexed with an arylamine: Insights into substrate recognition and correlation with kinetics. Biochem 2002; 41: $7325-7333$.

[28] Antorini M, Herpoel-Gimbert I, Choinowski T, Sigoillot JC, Asther M, Winterhalter K, Piontek K. Purification, crystallisation and X-ray diffraction 
study of fully functional laccases from two ligninolytic fungi. Biochim Biophys Acta 2002; 1594: 109-114.

[29] Hakulinen N, Kiiskinen LL, Kruus K, Saloheimo M, Paananen A, Koivula A, Rouvinen J. Crystal structure of a laccase from Melanocarpus albomyces with an intact trinuclear copper site. Nat Struct Biol 2002; 9: 601-605.

[30] Garavaglia S, Cambria MT, Miglio M, Ragusa S, Lacobazzi V, Palmieri F, D'Ambrosio C, Scaloni A, Rizzi M. The structure of Rigidoporus lignosus laccase containing a full complement of copper ions, reveals an asymmetrical arrangement for the T3 copper pair. J Mol Biol 2004; 342: 1519-1531.

[31] Enguita FJ, Martins LO, Henriques AO, Carrondo MA. Crystal structure of a bacterial endospore coat component - a laccase with enhanced thermostability properties. J Biol Chem 2003; 278: 19416-19425.

[32] Enguita FJ, Marcal D, Martins LO, Grenha R, Henriques AO, Lindley PF, Carrondo MA. Substrate and dioxygen binding to the endospore coat laccase from Bacillus subtilis. J Biol Chem 2004; 279: 23472-23476.

[33] Thurston CF. The structure and function of fungal laccase. Microbiol 1994; 140:19-26.

[34] Gianfreda L, Xu F, Bollag JM. Laccases: a useful group of oxidoreductive enzymes. Bioremed J 1999; 3: 1-25.

[35] Bajpai P. Application of enzymes in the pulp and paper industry. Biotechnol Prog 1999; 15: 147-157.

[36] Rochefort D, Leech D, Bourbonnais R. Electron-transfer mediator systems for bleaching of paper pulp. Green Chem 2004; 6: 14-24.

[37] Sergio R. Laccases: blue enzymes for green chemistry. Trends Biotechnol 2006; 24: 219-226.

[38] Schneider P, Pedersen AH. Enhancement of laccase reactions with aromatic ring-containing organic compounds and use of enzyme compositions in detergents and for water purification and pulp bleaching. (Novo Nordisk A/S, Den.). World Patent 1995; p. 77.

[39] Eggert C, Temp U, Eriksson KEL. Laccase is essential for lignin degradation by the white-rot fungus Pycnoporus cinnabarinus. FEBS Lett 1997; 407: 89-92.

[40] Xu F, Kulys JJ, Duke K, Li K, Krikstopaitis K, Deussen HJ, Abbate E, Galinyte $\mathrm{V}$, Schneider P. Redox chemistry in laccase-catalyzed oxidation of N-hydroxy compounds. Appl Environ Microbiol 2000; 66: 2052-2056.

[41] Johannes C, Majcherczyk A, Hutterman A. Oxidation of acenaphtalene and acenaphthylene by laccase of Trametes versicolor in a laccase- mediator system. J Biotechnol 1998; 61: 151-156.

[42] Nagai, M., Sato, T., Watanabe, H., Ei, H., Hirano, T.: JP2004000159 A2 (2004).

[43] Nagata, T., Hosoda, H., Sakagami, K.: JP2006304790 A2 (2006).

[44] Martins LO, Soares CM, Pereria MM, Teixeira M, Costa T, Jones GH, Henriques AO. Molecular and biochemical characterization of a highly stable 
bacterial laccase that occurs as a structural component of the Bacillus subtilis endospore coat. J Biol Chem 2002; 277: 18849-18859.

[45] Chefetz B, Chen Y, Hadar Y. Purification and characterization of laccase from Chaetomium thermophilium and its role in humification. Appl Environ Microbiol 1998; 64: 3175-3179.

[46] Schneider P, Caspersen MB, Mondorf K, Halkier T, Skov LK, Ostergaard PR, Brown KM, Brown SH, Xu F. Characterization of a Coprinus cinereus laccase. Enz Microb Technol 1999; 25: 502-508.

[47] Heinzkill M, Bech L, Halkier T, Schneider P, Anke T. Characterization of laccases from wood-rotting fungi (family Coprinaceae). Appl Environ Microbiol 1998; 64: 1601-1606.

[48] Kruus, K., Kiiskinen, L.-L., Raettoe, M., Viikari, L., Saloheimo, M.: WO2001092498 A1 (2001).

[49] Bulter T, Alcalde M, Sieber V, Meinhold P, Schlachtbauer C, Arnold FH. Functional expression of a fungal laccase in Saccharomyces cerevisiae by directed evolution. Appl Environ Microbiol 2003; 69:987-995.

[50] Palmieri G, Giardina P, Bianco C, Scaloni A, Capasso A, Sannia G. A novel white laccase from Pleurotus ostreatus. J Biol Chem 1997; 272: 31301-31307.

[51] Soden DM, O'Callaghan J, Dobson ADW. Molecular cloning of a laccase isozyme gene from Pleurotus sajor-caju and expression in the heterologous Pichia pastoris host. Microbiol 2002; 148: 4003-4014.

[52] Record E, Punt PJ, Chamkha M, Labat M, van Den Hondel CAMJJ, Asther M. Expression of the Pycnoporus cinnabarinus laccase gene in Aspergillus niger and characterization of the recombinant enzyme. Eur J Biochem 2002; 269: 602-609.

[53] Arias ME, Arenas M, Rodriguez J, Soliveri J, Ball AS, Hernandez M. Kraft pulp biobleaching and mediated oxidation of a nonphenolic substrate by laccase from Streptomyces cyaneus CECT 3335. Appl Environ Microbiol 2003; 69: 19531958.

[54] Paloheimo, M., Valtakari, L., Puranen, T., Kruus, K., Kallio, J., Mantyla, A., Fagerstrom, R., Ojapalo, P., Vehmaanpera, J.: US2006063246 A1 (2006).

[55] Galhaup C, Goller S, Peterbauer CK, Strauss J, Haltrich D. Characterization of the major laccase isoenzyme from Trametes pubescens and regulation of its synthesis by metla ions. Microbiol 2002; 148: 2159-2169.

[56] Garzillo AMV, Colao MC, Caruso C, Caporale C, Celletti D, Buonocore V. Laccase from the white-rot fungus Trametes trogii. Appl Microbiol Biotechnol 1998; 49: 545-551.

[57] Jung $\mathrm{H}, \mathrm{Xu} \mathrm{F}, \mathrm{Li}$ K. Purification and characterization of laccase from wooddegrading fungus Trichophyton rubrum LKY-7. Enz Microb Technol 2002; 30:161-168.

[58] Slomezynski D, Nakas JP, Tanenbaum SW. Production and characterization of laccase from Botrytis cinerea 61-34. Appl Environ Microbiol 1995; 61: 907912. 
[59] Edens WA, Goins TQ, Dooley D, Henson JM. Purification and characterization of a secreted laccase of Gaemannomyces graminis var. tritici. Appl Environ Microbiol 1999; 65: 3071-3074.

[60] Kojima, Y., Kita, Y., Tsukuda, Y.: EP0388166 (1990).

[61] Kruus, K., Kiiskinen, L.-L., Ratto, M., Viikari, L., Saloheimo, M.: US7183090 (2007).

[62] Yasuchi, K., Yukio, K., Yukiko, T.: EP0388166 (1990).

[63] Kiiskinen L-L, Kruus K, Bailey M, Ylosmaki E, Siika-aho M, Saloheimo M. Expression of Melanocarpus albomyces laccase in Trichoderma reesei and characterization of the purified enzyme. Microbiol 2004; 150: 3065-3074.

[64] Saloheimo M, Niku-Pavola M-L. Heterologous production of a ligninolytic enzyme: expression of the Phlebia radiate laccase gene in Trichoderma reesei. Biotechnol 1991; 9: 987-990.

[65] Yaver DS, Xu F, Golightly EJ, Brown KM, Brown SH, Rey MW, Schneider P, Halkier T, Mondorf K, Dalboge H. Purification, characterization, molecular cloning, and expression of two laccase genes from the white not basidiomycete Trametes villosa. Appl Environ Microbiol 1996; 62:834-841.

[66] Yaver DS, Overjero MJ, Xu F, Nelson BA, Brown KM, Halkier T, Bernuer S, Brown SH, Kauppinen S. Molecular characterization of laccases genes from the basidiomycete Coprinus cinereus and heterologous expression of the laccase lccl. Appl Environ Microbiol 1999; 65: 4943-4948.

[67] Wahleithner JA, Xu F, Brown SH, Golightly EJ, Halkier T, Kauppinen S, Pederson A, Schneider P. The identification and characterization of four laccases from the plant pathogenic fungus Rhizoctonia solani. Curr Genet 1996; 29: 395403.

[68] Berka, R.M., Brown, S.H., Xu, F., Schneider, P.: US5795760 (1998).

[69] Berka, R.M., Thompson, S.A., Xu, F. US5843745 (1998).

[70] Ishida, H., Hata, Y., Abe, Y., Akao, T.: JP2002218983 A2 (2002).

[71] Sigoillot C, Record E, Belle V, Robert JL, Levasseur A, Punt PJ, Van Den Hondel CA, Fournel A, Sigoillot JC, Asther M. Natural and recombinant fungal laccases for paper pulp bleaching. Appl Microbiol Biotechnol 2004; 64: 346352.

[72] Jonsson LJ, Saloheimo M, Penttila M. Laccase from the white-rot fungus Trametes versicolor: cDNA cloning of lcc1 and expression in Pichia pastoris. Curr Genet 1997; 32: 425-430.

[73] Otterbein L, Record E, Longhi S, Asther M, Moukha S. Molecular cloning of the cDNA encoding laccase from Pycnoporus cinnabarinus 1-937 and expression in Pichia pastoris. Eur J Biochem 2000; 267: 1619-1625.

[74] Brown MA, Zhao Z, Mauk AG. Expression and characterization of a recombinant multi-copper oxidase: laccase IV from Trametes versicolor. Inorg Chim Acta 2002; 331: 232-238. 
[75] Liu W, Chao Y, Lii S, Bao H, Qian S. Molecular cloning and characterization of a laccase gene from the basidiomycete Fome lignosus and expression in Pichia pastoris. Appl Microbiol Biotechnol 2003; 63: 174-181.

[76] Qian, S., Liu, W., Chao, Y.: CN1594543 A (2005).

[77] Madzak C, Otterbein L, Chamkha M, Moukha S, Asther M, Gaillardin C, Beckerich J-M. Heterologous production of a laccase from the basidomycete Pycnoporous cinnabarinus in the dimorphic yeast Yarrowia lipolytica. FEMS Yeast Res 2005; 5: 635-646.

[78] Hatamoto O, Sekine H, Nakano E, Abe K. Cloning and expression of a cDNA encoding the laccase from Schizophyllum commune. Biosci Biotechnol Biochem 1999; 63: 58-64.

[79] Larrondo LF, Avila M, Salas L, Cullen D, Vicuna R. Heterologous expression of laccase cDNA from Ceriporiopsis subvermispora yields copper-activated apoprotein and complex isoform patterns. Microbiol 2003; 149: 1177-1182.

[80] Karos, M., Subkowski, T., Lemaire, H.-G., Bollschweiler, C., Nuesslein, B., Fischer, R.: DE102004047409 A1 (2006).

[81] Arnaut, F., Dauvrin, T., Contreras, R., Vanneste, G., Viaene, J.: EP1637595 A1 (2006).

[82] LaFayette PR, Eriksson KE, Dean JF. Characterization and heterologous expression of laccase cDNAs from xylem tissues of yellow-poplar (Liriodendron tulipifera). Plant Mol Biol 1999; 40: 23-35.

[83] Iimura, Y., John, A.H.: EP1300469 (2003).

[84] Iimura, Y., John, A.H.: US7169965 (2007).

[85] Yoshihiro, K., Yosuke, I.: US7169965 (2007).

[86] Bailey MR, Woodard SL, Callaway E, Beifuss K, Magallanes-Lundback M, Lane JR, Horn ME, Mallubhotla H, Delaney DD, Ward M, Van Gastel F, Howard JA, Hood EE. Improved recovery of active recombinant laccase from maize seed. Appl Microbiol Biotechnol 2004; 63: 390-397.

[87] Elizabeth, H., John, A.H., Joseph, J.: US6800792 (2004).

[88] Chen, X., Wang, G.: CN1607249 A (2005).

[89] Suzuki, T., Endo, Y., Ito, M., Tsujibo, Y., Miyamoto, K., Inamori, Y.: JP2003230392 A2 (2003).

[90] Gong, W.: CN1560257 A (2005).

[91] Miyazaki, K.: JP2006158252 A2 (2006).

[92] Larsson S, Cassland P, Jonsson LJ. Development of a Sacharomyces cerevisiae strain with enhanced resistances to phenolic fermentation inhibitors in lignocellulose hydrolysates by heterlogous expression of laccase. Appl Environ Microbiol 2001; 67: 1163-1170.

[93] O'Callaghan J, O'Brien MM, McClean K, Dobson ADW. Optimisation of the expression of a Trametes versicolor laccase gene in Pichia pastoris. J Ind Microbiol Biotechnol 2002; 29: 55-59.

[94] Marbach-Ringhandt, K., Pfaller, R., Uldschmid, A.: DE10046932 A1 (2002). 
[95] Uldschmid A, Dombi R, Marbach K. Identification and functional expression of ctaA, a P-type ATPase gene involved in copper trafficking in Trametes versicolor. Microbiol 2003; 149: 2039-2048.

[96] Alves AMCR, Record E, Lomascolo A, Scholtmeijer K, Asther M, Wessels $\mathrm{JGH}$, Wosten HAB. Highly efficient production of laccase by the basidiomycete Pycnoporus cinnabarinus. Appl Environ Microbiol 2004; 70: 6379-6384.

[97] Alves, A., Record, E., Lomascolo, A., Sigoillot, J.C., Asther, M., Wosten, H.A.B.: FR2865216 A1 (2005).

[98] Germann UA, Lerch K. Isolation and partial nucleotide sequence of the laccase gene from Neurospora crassa: Amino acid sequence homology of the protein to human ceruloplasmin. Proc Natl Acad Sci USA 1986; 83: 8854-8858.

[99] Aramayo R, Timberlake WE. Sequence and molecular structure of the Aspergillus nidulans yA (laccase I) gene. Nucleic Acids Res 1990; 18: 34153415.

[100] Saloheimo M, Niku-Paavola M-L, Knowles JK. Isolation and structural analysis of the laccase gene from the lignin-degrading fungus Phelbia radiata. J Gen Microbiol 1991; 137: 1537-1544.

[101] Perry CR, Smith M, Britnell CH, Wood DA, Thurston CF. Identification of two laccase genes in the cultivated mushroom Agaricus bisporus. J Gen Microbiol 1993; 139: 1209-1218.

[102] Eggert C, LaFayette PR, Temp U, Eriksson KEL, Dean JFD. Molecular analysis of a laccase gene from the white rot fungus Pycnoporus cinnabarinus. Appl Environ Microbiol 1998; 64: 1766-1772.

[103] Mikuni J, Morohoshi N. Cloning and sequencing of a second laccase gene from the white-rot fungus Coriolus versicolor. FEMS Microbiol Lett 1997; 155: 7984.

[104] Fermandez-Larrea J, Stahl U. Isolation and characterization of a laccase gene from Podospora anserine. Mol Gen Genet 1996; 252: 539-551.

[105] Leem Y, Kim S, Ross IK, Choi HT. Transformation and laccase mutant isolation in Coprinus congregatus by restriction enzyme- mediated integration. FEMS Microbiol Lett 1999; 172: 35-40.

[106] D'Souza TM, Boominathan K, Reddy CA. Isolation of laccase gene specific sequences from white rot and brown rot fungi by PCR. Appl Environ Microbiol 1996; 62: 3739-3744.

[107] Germann UA, Muller G, Hunziker PE, Lerch K. Characterization of two allelic forms of Neurospora crassa laccase. Amino-and carboxyl-terminal processing of a precursor. J Biol Chem 1988; 263: 885-896.

[108] Xu F, Berka RM, Wahleithner JA, Nelson BA, Shuster JR, Brown SH, Palmer AE, Solomon EI. Site-directed mutations in fungal laccase: effect on redox potential, acitivity and $\mathrm{pH}$ profile. Biochem J 1998; 334: 64-70.

[109] Xu F, Palmer AE, Yaver DS, Berka RM, Gambetta GA, Brown SH, Solomon EI. Targeted mutations in a Trametes villosa laccase. J Biol Chem 1999; 274: 12372-12375.

[110] Schouten, A., Van Kan Johannes, A.L., Stefanato, F.L., Sibbel-Wagemakers, 


\section{C.A.M.: EP1167528 A1 (2002).}

[111] Karahanian E, Corsini G, Lobos S, Vicuna R. Structrue and expression of a laccase gene from the ligninolytic basidiomycete Ceriporiopsis subvermispora. Biochim Biophys Acta 1998; 1443: 65-74.

[112] Williamson PR. Biochemical and molecular characterization of the diphenol oxidase of Cryptococcus neoformans: identification as a laccase. J Bacteriol 1994; 176:656-664.

[113] Dedeyan B, Klonowska A, Tagger S, Tron T, Lacazio G, Gil G, Le Petit J. Biochemical and molecular characterization of a laccase from Marasmius quercophilus. Appl Environ Microbiol 2000; 66: 925-929.

[114] Giardina P, Palmieri G, Scaloni A, Fontanella B, Faraco V, Cennamo G, Sannia G. Protein and gene structure of a blue laccase from Pleurotus ostreatus. Biochem $\mathrm{J}$ 1999; 341: 655-663.

[115] Giardina P, Aurilia V, Cannio R, Marzullo L, Amoresano A, Siciliano R, Pucci $\mathrm{P}$, Sannia G. The gene, protein and glycan structures of laccase from Pleurotus ostreatus. Eur J Biochem 1996; 235: 508-515.

[116] Ranocha P, McDougall G, Hawkins S, Sterjiades R, Borderies G, Stewart D, Cabanes-Macheteau M, Boudet A.M., Goffner D. Biochemical characterization, molecular cloning and expression of laccases-a divergent gene family- in poplar. Eur J Biochem 1999; 259: 485-495.

[117] Bourbonnais R, Paice MG, Reid ID, Lanthier P, Yaguchi M. Lignin oxidation by laccase isozymes from Trametes versicolor and role of the mediator 2,2'azinobis (3-ethylbenzthiazoline-6-sulfonate) in Kraft lignin depolymerization. Appl Environ Microbiol 1995; 61: 1876-1880.

[118] Cassland P, Jonsson LJ. Characterization of a gene encoding Trametes versicolor laccase A and improved heterologous expression in Saccharomyces cerevisiae by decreased cultivation temperature. Appl Microbiol Biotechnol 1999; 52: 393-400.

[119] Luisa M, Goncalves FC, Steiner W. Purification and characterization of laccase from a newly isolated wood-decaying fungus. In: Enzymes for pulp and paper processing. Eds.: Jeffries TW, Viikari IL. American Chemical Society. Washington, USA, 1996; 258-266.

[120] Barreca AM, Fabbrini M, Galli C, Gentili P, Ljunggren S. Laccase/mediated oxidation of a lignin model for improved delignification procedures $\mathrm{J}$ Mol Catal B-Enzym 2003; 26: 105-110.

[121] Gamelas JAF, Tavares APM, Evtuguin DV, Xavier AMB. Oxygen bleaching of kraft pulp with polyoxometalates and laccase applying a novel multi-stage process. J Mol Catal B-Enzym 2005; 33: 57-64.

[122] Shi, J.: CN1844572 A (2006).

[123] Xu, H., Bloomfield, K., Lund, H.: WO2006126983 A1 (2006).

[124] Bourbonnais R, Paice MG, Freiermuth B, Bodie E, Borneman S. (1997) Reactivities of various mediators and laccases with kraft pulp and lignin model compounds. Appl Environ Microbiol 1997; 12: 4627-4632. 
[125] Call HP, Mucke I. History, overview and applications of mediated lignolytic systems, especially laccase-mediator-systems. J Biotechnol 1997; 53:163-202.

[126] Cheng, H.N., Delagrave, S., Gu, Q-M., Michalopoulos, D., Murphy, D.J.: WO2003023142 A1 (2003).

[127] Cheng, H.N., Delagrave, S., Gu, Q-M., Michalopoulos, D., Murphy, D.J.: WO2003023043 A1 (2003).

[128] Cheng, H.N., Delagrave, S., Gu, Q-M., Michalopoulos, D., Murphy, D.J.: US2003047295 A1 (2003).

[129] Diao, Y., Fu, S.: CN1374403 A (2002).

[130] Hamada, N., Saito, T.: JP2006246802 A2 (2006).

[131] Guo, L., Wang, W., Zhang, H., Li, W.: CN1621519 A (2005).

[132] Tsukamoto, A., Nakagame, S., Kabuto, M.: WO2003070939 A1 (2003).

[133] Felby, C., Hansen, T.T.: US6045865 (2000).

[134] Xu, L., Yang, M., Mu, H., Wang, H., Zhao, Y.: CN1804210 A (2006).

[135] Qin, M., Xu, Q., Fu, Y., Tang, Z.: CN1786339 A (2006).

[136] Qin, M.; Xu, Q., Fu, Y., Li, Z.: CN1793488 A (2006).

[137] He, B., Lin, L.: CN1718918 A (2006).

[138] Gonzalez, B., Aldo, E., Villar, G., Juan, C., Silva, S., Ricardo, A.: ES2221529 A1 (2004).

[139] Popovici, C., Tolan, J.: CA2349429 AA (2001).

[140] Amidon, T.E., Francis, R., Scott, G.M., Bartholomew, J., Ramarao, B.V., Wood, C.D.: WO2006121634 A2 (2006).

[141] Camarero, S., Garcia, O., Vidal, T., Colom, J.F., Del Rio, J.C., Gutierrez Suarez, A., Martinez, M.J., Sigoillot, J.C., Asther, M., Martinez, A.T.F.: WO2003052201 A1 (2003).

[142] Call, H.P.: WO2005103372 A2 (2005).

[143] Guebitz GM, Cavaco Paulo A. New substrates for reliable enzymes: enzymatic modification of polymers. Curr Opn Biotechnol 2003; 14: 577-582.

[144] Xu, Q., Fu, Y., Qin, M., Li, Z.: CN1763305 A (2006).

[145] Pedersen, L.S., Felby, C., Munk, N.: US 6187136 (2001).

[146] Shi, C., Lund, H., Vogt, U.: WO2001048304 A1 (2001).

[147] Franks, N.E.: US6241849 B1 (2001).

[148] Zhao, W., Ma, Q., Xu, S., Zhang, H.: CN1594729 A (2005).

[149] Wang, X.H., Ma, J.H., Jiang, C.L., Brown, W.D. Jr.: WO2007035481 (2007).

[150] Srebotnik, E.: WO2005028561 A1 (2005).

[151] Vikari, L., Qvintus-Leino, P., Tuominen, S., Gadda, L., Niku-Paavola, M-L.: US6245269 (2001). 
[152] Gadda, L., Hase, A., Kataja, K., Qvintus-Leino, P., Tuominen, S., Vikari, L.: US6287708 (2001).

[153] Hansen, T.T., Holm, H.C., Franks, N.E.: US5603804 (1997).

[154] Mayer AM, Staples RC. Laccase: new functions for an old enzyme. Phytochem 2002; 60: 551-565.

[155] Tzanov, T.Z., Cavaco-Paulo, A.: PT102779 (2003).

[156] Zhu, Q., Wu, C., Chen, X., Gu, Z., Guo, L.: CN1584192 A (2005).

[157] Cavaco Paulo, A., Tzanov, T., Guebitz, G.: PT102779 A (2003).

[158] Pazarloglu NK, Sariisik M, Telefoncu A. Laccase: production by Trametes versicolor and application to denim washing. Process Biochem 2005; 40: 16731678 .

[159] Xu F. In: The encyclopedia of bioprocessing technology: fermentation, biocatalysis, and bioseparation. Eds.: Flickinger MC, Drew SW. John Wiley \& Sons, New York, 1999; 1545-1554.

[160] Shi, C., Clemmons, J.: WO2003016615 A1 (2003).

[161] Paloheimo, M., Valtakari, L., Puranen, T., Kruus, K., Kallio, J., Mantyla, A., Fagerstrom, R., Ojapalo, P., Vehmaanpera, J.: US20060063246 A1 (2006).

[162] Paloheimo, M., Puranen, T., Valtakari, L., Kruus, K., Kallio, J., Maentylae, A., Fagerstroem, R., Ojapalo, P., Vehmaanperae, J.: WO2006032724 A2 (2006).

[163] Pedersen, A.H., Schneider, P.T.N.N.: US5795855 A (1998).

[164] Barfoed, M., Kirk, O., Salmon, S.: WO2001044563 A1 (2001).

[165] Kitamoto, N., Chatani, E., Hangai, A.: JP2004141027 A2 (2004).

[166] Kitano, M., Yamamoto, S., Kitamoto, N., Yasuda, S., Chatani, E., Nakatani, T., Shimizu, Y.: JP2003247174 A2 (2003).

[167] Aaslyng, D., Rorbaek, K., Sorensen, N.H.: WO9719999 (1997).

[168] Aaslyng, D., Sorensen, N.H., Rorbaek, K.: US5948121 (1999).

[169] Sorensen, N.H.: WO9915137 (1999).

[170] Rorbaek, K., Aaslyng, D., Sorensen, N.H.: AU7622096 (1997).

[171] Martin, R., Jumino, A., Dubief, C., Rosenbaum, G., Audousset, M.P.: FR2694018 (1994).

[172] Nagai, M., Sato, T., Hyuga, K.: JP2005348693 A2 (2005).

[173] Jiang, S., Wu, H., Cui, P., Li, Z., Chu, X., Wang, X., Chen, L., He, L.: CN1733982 A (2006).

[174] Kirk O, Borchert TV, Fuglsang CC. Industrial enzyme applications. Curr Opin Biotechnol 2002; 13: 345-351.

[175] Shimotsuura, I., Tobe, S.: JP2002051768 A2 (2002).

[176] Someya, K., Yoshino, T., Asai, Y.: JP2003009856 A2 (2003).

[177] Hiramoto, T., Abe, K.: WO2004103329 A1 (2004).

[178] Wolfgang, A., Baldwin, T.M., Van Gastel, F.J.C., Janssen, G.G., Murray, C.J., 
Wang, H., Winetzky, D.S.: US2005058996 A1 (2005).

[179] Aehle, W., Baldwin, T.L., Janssen, G.G., Murray, C.J., Van Gastel, F.J.C., Wang, H., Winetzky, D.S.: WO2003023067 A1 (2003).

[180] Yoon, M.Y.: WO98/27264 (1998).

[181] Lantto R, Schonberg C, Buchert J, Heine E. Effects of laccase-mediator combinations on wool. Textile Res J 2004; 74:713-717.

[182] Farneth, W.E., Hasty, N.M., Damore, M.B., Chisholm, D.A.: WO2005033676 A1 (2005).

[183] Petersen, B.R., Mathiasen, T.E.: WO 9631133 A1 (1996).

[184] Takemori, T., Ito, Y., Ito, M., Yoshama, M.: JP 04126037 A2 (1992).

[185] Sato, H., Koyama, S.: JP2006149235 A2 (2006).

[186] Anon. Renoval of off-flavors in food. Res Disclos 1999; 424: 1045-1046.

[187] Tsuchiya, R., Petersen, B. R., Christensen, S.: US 6074631 A (2000).

[188] Bouwens, E.M., Trivedi, K., Van Vliet, C., Winkel, C.: EP760213 A1 (1997).

[189] Bouwens, E.M., Trivedi, K., Van Vliet, C., Winkel, C.: US5879730 A (1999).

[190] Bloom, M., Van Zyl, W.H., Joubert, E., Botha, A., De Villiers, D.: WO2006013530 A1 (2006).

[191] Micard V, Thibault JF. Oxidative gelation of sugar-beet pectins: use of laccases and hydratation properties of the cross-linked pectins. Carbohyd Polym 1999; 39: $265-273$.

[192] Piacquadio P, De Stefano G, Sammartino M, Sciancalepore V. Apple juice stabilization by laccase immobilized on metal chelate regenerable carriers. Industrie delle Bevande 1998; 27: 378-383.

[193] Alper N, Acar J. Removal of phenolic compounds in pomegranate juices using ultrafiltration and laccase-ultrafiltration combinations. Nahrung 2004; 48: 184187.

[194] Si, J.Q. : WO 9428728 A1 (1994).

[195] Servicetech Japan, Ygshinwa, K.K.: JP2004267177-A (2004).

[196] Descenzo, R.A., Irelan, N.A.: US2003033627-A1 (2003).

[197] Schmedding, D.J.M., Hennink, H., Van Gestel, M.J.M.C., Smith, C.J.: EP1122303 A1 (2001).

[198] Angele, L., Degre, M.: EP 543722 A1 (1993).

[199] Tannoven D, Eksi A. Phenolic compounds in pear juice from different cultivars. Food Chem 2005; 93: 89-93.

[200] Mathiasen, T.E.: WO9521240 A2 (1995).

[201] Sato, O., Kusayama, Y., Kitatani, T.: JP2004267177 A2 (2004).

[202] Conrad, L.S., Sponholz, W.R., Berker, O.: US6152966 (2000).

[203] Nishida, T., Kanohata, M.: JP2003128835 A2 (2003).

[204] Nishida, T., Kanohata, M.: JP2003128836 A2 (2003). 
[205] Kimura, T., Watanabe, T.: JP2004339438 A2 (2004).

[206] Uematsu, H., Watanabe, Y., Isshiki, K., Kurane, R.: JP2001245654 A2 (2001).

[207] Saito, T., Kato, K., Yokokawa, Y.: JP2004041124 A2 (2004).

[208] Nakatani, M., Yoshida, M.: JP2003117569 A2 (2003).

[209] Chakar, F.S., Ragauskas, A.J.: US6294047 B1 (2001).

[210] Xu, H., Lund, H., Luo, J., Bloomfield K.: WO2004112843 A2 (2004).

[211] Maximo C, Costa-Ferreira M. Decolourisation of reactive textile dyes by Irpex lacteus and lignin modifying enzymes. Process Biochem 2004; 39: 1475-1479.

[212] Novotny C, Svobodova K, Kasinath A, Erbanova P. Biodegradation of synthetic dyes by Irpex lacteus under various growth conditions. Int Biodeterior Biodegrad 2004; 54: 215-223.

[213] Raghukumar, C., D'Souza, T.M., Thorn, R.G., Reddy, C.A.: US6395534 B1 (2002).

[214] D’Annibale A, Stazi SR, Vinciguerra V, Giovannozzi Sermanni G. Oxiraneimmobilized Lentinula edodes laccases: stability and phenolics removal efficiency in olive mill wastewater. J Biotechnol 2000; 77: 265-273.

[215] Manzanares P, Fajardo S, Martin C. Production of ligninolytic activities when treating paper pulp effluents by Trametes versicolor. J Biotechnol 1995; 43: 125-132.

[216] Caballero, N.E.D., Pastore, G.M., Minussi, R.C., Cordi, L.: BR2000002329 A (2002).

[217] Miyamoto, H., Kawabata, T., Suzuki, M.: CA2388446 (2001).

[218] Duncan, KW.: NZ527024 A (2004).

[219] Suzuki, M., Kawabata, T., Shimazaki, A.: JP2002153257 A2 (2002)

[220] Suzuki, N., Tachibana, M., Uenaka, T., Toriyama, A., Kurane, R.: JP2004130166 A2 (2004).

[221] Boehmer, S., Srebotnik, E., Messner, K.: AT407049 B (2000).

[222] Kawabata, T., Miyamoto, H., Suzuki, G.: JP2001252646 A2 (2001).

[223] Kajiuchi, T., Hayakawa, Y., Okawa, H., Hong, K.K.: JP2006094811 A2 (2006).

[224] Suzuki, G., Miyamoto, H., Kawabata, T.: JP2001232345 A2 (2001).

[225] Suzuki, M., Miyamoto, H., Kawabata, T.: JP2001232346 A2 (2001).

[226] Shirai, N., Okada, T., Matsumoto, T., Watanabe, T.: JP2005160330 A2 (2005).

[227] Aggelis G, Iconomou D, Christou M, Bokas D, Kotzailias S, Christou G, Tsagou V, Papanikolaou S. Phenolic removal in a model olive oil mill wastewater using Pleurotus ostreatus in bioreactor cultures and biological evaluation of the process. Water Res 2003; 37: 3897-3904.

[228] Schlosser, D., Grey, R., Hoefer, C., Schneegass, I., Guenther, K., Fassler, D.: DE 19744700 A1 (1999). 
[229] Hublik G, Schinner F. Characterization and immobilization of the laccase from Pleurotus ostreatus and its use for the continuous elimination of phenolic pollutants. Enz Microb Technol 2000; 27: 330-336.

[230] Cavaco Paulo, A., Tzanov, T., Costa, S., Abreu, A., Carneiro, A., Gubitz, G.: PT102427 A (2001).

[231] Sun, X., Ren, C., Ao, X.: CN1778912 A (2006).

[232] Kozaki, S., Goto, M., Okazaki, S., Michizoe, J.: JP2003052367 A2 (2003).

[233] Guebitz, G., Cavaco-Paulo, A., Kandelbauer, A., Schroeder, M., Held, C.I.: EP1468968 A1 (2004).

[234] Leontievsky AA, Myasoedova NM, Baskunov BP, Evans CS, Golovleva LA. Transformation of 2,4,6-trichlorophenol by the white rot fungi Panus tigrinus and Coriolus versicolor. Biodegrad 2000; 11: 331-340.

[235] Niku PML, Viikari L. Enzymatic oxidation of alkenes. J Mol Catal B-Enzym 2000; 10: 435-444.

[236] Bressler DC, Fedorak PM, Pickard MA. Oxidation of carbazole, Nethylcarbazole, fluorene, and dibenzothiophene by the laccase of Coriolopsis gallica. Biotech Lett 2000; 22: 119-1125.

[237] Mougin C, Boyer FD, Caminade E, Rama R. Cleavage of the diketonitrile derivative of the herbicide isoxaflutole by extracellular fungal oxidases. J Agric Food Chem 2000; 48: 4529-4534.

[238] Alcalde M, Ferrer M, Plou FJ, Ballesteros A. Environmental biocatalysis: from remediation with enzymes to novel green processes. Trends Biotechnol 2006; 24: 281-287.

[239] Milstein O, Nicklas B, Hütttermann A. Oxidation of aromatic compounds in organic solvents with laccase from Trametes versicolor. Appl Microbiol Biotechnol 1989; 31: 70-74.

[240] Kobayashi S, Higashimura H. Oxidative polymerization of phenols revisited. Prog Polym Sci 2003; 28: 1015-1048.

[241] Mita N, Tawaki SI, Hiroshi U, Kobayashi S. Laccase-catalyzed oxidative polymerization of phenols. Macromol Biosci 2003; 3: 253-257.

[242] Ikeda R, Tanaka H, Oyabu H, Uyama H, Kobayashi S. Preparation of artificial urushi via an environmentally benign process. Bull Chem Soc Jpn 2001; 74: 1067-1073.

[243] Ikeda R, Tanaka H, Uyama H, Kobayashi S. Laccase-catalyzed polymerization of acrylamide. Macromol Rapid Commun 1998; 19: 423-425.

[244] Budolfsen, G., Jensen, M.T., Heldt-Hansen, H.P., Stringer, M.A., Lange, L.: WO2004032648 A1 (2004).

[245] Aktas N, Tanyolac A. Kinetics of laccase-catalyzed oxidative polymerization of catechol. J Mol Catal B: Enz 2003; 22: 61-69.

[246] Karamyshev AV, Shleev SV, Koroleva OV, Yaropolov AI, Sakharov IY. Laccase-catalyzed synthesis of conducting polyaniline. Enz Microb Technol 2003; 33: 556-564. 
[247] Gureir M, Akta N, Tanyolaç A. Influence of reaction conditions on the rate of enzymic polymerization of pyrogallol using laccase. Process Biochem 2005; 40: 1175-1182.

[248] Samuelson, L.A., Tripathy, S.K., Bruno, F., Nagarajan, R., Kumar, J., Liu, Wei.: US 6569651 B1 (2003).

[249] Schoevaart, W.R.K., Van Langen, L.M., Van Den Dool, R.T.M., Boumans, J.W.L.: WO2006046865 A2 (2006).

[250] Jetten, J.M., van den Dool, R., Van Hartingsveldt, W., Cornelis, B.A.: WO 9950463 (2000).

[251] Jetten, J.M., Timmerman, E.J.G., Cornelis, B.A., Van den Dool, R.T.M., Boumans, J.W.L.: WO2003040190 A1 (2003).

[252] Jetten, J.M., van den Dool, R.T.M., Van Hartingsveldt, W., Van Wandelen, M.T.R.: US6831173 (2004).

[253] Viikari, L., Kruus, K., Buchert, J.: WO9923117 (1999).

[254] Besemer, A.C., Jetten, J.M., van den Dool, R.: US6716976 (2004).

[255] Kimura, T.: JP2006262728 A2 (2006).

[256] Wariishi, H., Nonaka, D., Nishihashi, S., Hirahashi, T., Ito, K.: JP2006280259 A2 (2006).

[257] Wariishi, H., Nonaka, D., Nishihashi, S., Hirahashi, T., Ito, K.: JP2006280260 A2 (2006).

[258] An, E.S., Kim, S.C., Kim, Y.H., Park, S.Y., Ryu, J.Y., Song, B.K., Song, J.K.: KR2005011958 A (2005).

[259] Takahara, J.: JP2004313057 A2 (2004).

[260] Yamagishi, K., Shibafuji, M., Shido, K., Nakata, H.: JP2003292610 A2 (2003).

[261] Hirao, K., Shirai, N., Yamanaka, M., Nakajima, H., Nakay, T., Minoda, M.: JP2006045414 A2 (2006).

[262] Sumi, K., Ishii, T., Suzuki, M.: WO2004100660 A1 (2004).

[263] Lartey, R.T., Caesar, T.: US6872388 B1 (2005).

[264] Nicotra S, Cramarossa MR, Mucci A, Pagnoni UM, Riva S, Forti L. Biotransformation of resveratrol: synthesis of trans-dehydrodimers catalyzed by laccases from Myceliophtora thermophyla and from Trametes pubescens. Tetrahedr 2004; 60: 595-600.

[265] Haught, J.C., Miracle, G.S., Convents, A.C.: WO2001060157 A2 (2001).

[266] Juelich, W.-D., Schauer, F., Lindequist, U., Hammer, E., Schaefer, A., Jonas, U.: WO2001098518 A2 (2001).

[267] Johansen, C.: WO9606532 A1 (1996).

[268] Molino, B.F., Haydar, S.N., Yang, Z., Michels, P.C., Hemenway, M.S., Rich, J.O., Khmelnitsky, Y.: WO2004082629 A2 (2004).

[269] Stahl P, Kissau L, Mazitschek R, Giannis A, Waldmann H. Natural product derived receptor tyrosin kinase inhibitors: Identification of IGF1R-, Tie-2 and VEGFR3 inhibitors. Angew Chem Int Ed 2002; 41: 1174-1178. 
[270] Oestergaard, L.H., Christensen, B.E., Danielsen, S.: WO2006094975 A2 (2006).

[271] Danielsen, S., Christensen, B.E., Schneider, P.: WO2003090542 A1 (2003).

[272] Wang HX, Ng TB. A novel laccase with fair thermostability from the edible wild mushroom (Albatrella dispansus). Biochem Biophys Res Commun 2004; 315: 450-454.

[273] Harris ZL, Davis-Kaplan SR, Gitlin JD, Kaplan J. A fungal multicopper oxidase restores iron homeostasis in aceruloplasminemia. Blood 2004; 103: 4672-4673.

[274] Bauer CG, Kuhn A, Gajovic N, Skorobogatko O, Holt PJ, Bruce NC, Makower A, Lowe CR, Scheller FW. New enzyme sensors for morphine and codeine based on morphine dehydrogenase and laccase. Fresenius J Anal Chem 1999; 364: 179-183.

[275] Lang, G., Cotteret, J.: US2004255401 A1 (2004).

[276] Koike, K.: JP2002255764 A2 (2002).

[277] Koike, K.: Saito, Y.: JP2002291496 A2 (2002).

[278] Pereira, R., Burgaud, H.: FR2863487 A1 (2005).

[279] Plos, G.: WO2004056331 A1 (2004).

[280] Plos, G.: FR2848836 A1 (2004).

[281] Shichiri, S., Morita, K., Koike, K.: JP2003055175 A2 (2003).

[282] Sorensen, N.H.: WO2001068042 A1 (2001).

[283] Onuki, T., Nogucji, M., Mitamura, J.: WO0037,030 (2000).

[284] Pruche, F., Saint, L.P., Bernards, B.: EP1013260 (2000).

[285] Kao Corporation, Japan.: DE20118615 U1 (2002).

[286] Lang, G., Plos, G.: WO2002007687 A1 (2002).

[287] Lang, G., Plos, G.: WO2002007688 A1 (2002).

[288] Tsuji, K., Yoshino, T., Asai, Y.: JP2002012535 A2 (2002).

[289] Plos, G.: EP1138318 A2 (2001).

[290] Golz-Berner, K., Walzel, B., Zastrow, L., Doucet, O.: WO2004017931 (2004).

[291] Yokoyama, M., Kusakari, T., Minami, K., Miyazawa, K.: JP2006070175 A2 (2006).

[292] Tachihara, T., Miyoshi, H., Komai, T.: JP2006325441 A2 (2006).

[293] Meiji Seika Kaisha Ltd, Inahata Koryo, K.K., Morishita Jintan, K.K.: JP2004321077 A (2004).

[294] Tsuchiya, R., Petersen, B.R., Christensens, S.: WO9909143 A (1999).

[295] Miyamoto, S., Kita, N., Tokita, F., Hirayama, T.: JP2005289918 A2 (2005).

[296] Omori, T., Akiyama, Y., Nagae, K.: JP2004321077 A2 (2004).

[297] Huybrechts, L.: WO2001064175 A1 (2001).

[298] Markussen, E.K., Jensen, P.E.: WO2006053564 A2 (2006). 
[299] Kozato, T., Uyama, H., Kurisawa, G., Zheng, Z.-E., Uemura, W.: JP2005289860 A2 (2005).

[300] Enomoto, K.: JP2005095033 A2 (2005).

[301] Roggen, E.L., Ernst, S., Svendsen, A., Friis, E.P., Von Der Osten, C.: WO2001083559 A2 (2001).

[302] D'Souza SF. Microbial biosensors. Biosens Bioelectr 2001; 16:337-353.

[303] Simkus RA, Laurinavicius V, Boguslavsky L, Skotheim T, Tanenbaum S, Nakas JP, Slomczynski DJ. Laccase containing sol-gel based optical biosensors. Anal Lett 1996; 29: 1907-1919.

[304] Freire RS, Duran N, Wang J, Kubota LT. Laccase-based screen printed electrode for amperometric detection of phenolic compounds. Anal Lett 2002; 35: 29-38.

[305] Gomes SASS, Nogueira JMF, Rebelo MJF. An amperometric biosensor for polyphenolic compounds in red wine. Biosens Bioelectr 2004; 20: 1211-1216.

[306] Willner, I., Katz, E.: WO2003019170 A1 (2003).

[307] Zeng, G., Tang, L., Zhang, Y., Niu, C., Shen, G., Huang, D.: CN1837809 A (2006)

[308] Kubota, L.T., Caballero, N.E.D., Freire, R.S.: BR2001006474 A (2003).

[309] Heller, A.: US2002172992 A1 (2002).

[310] Heller, A.: WO2002093152 A1 (2002).

[311] Scheller, F., Wollenberger, U., Makower, A.: DE4314417 A1 (1994).

[312] Ju, H., Du, D.: CN1588078 A (2005).

[313] Jennings, M., Mcewan, A., Huston, W.: WO2003000722 A1 (2003).

[314] Park DH, Vieille C, Zeikus JG. Bioelectrocatalysts: engineered oxidoreductase system for utilization of fumarate reductase in chemical synthesis, detection, and fuel cells. Appl Biochem Biotechnol 2003; 111: 41-53.

[315] Palmore GTR. Bioelectric power generation. Trends Biotechnol 2004; 22: 99100.

[316] Minteer, S.D., Martin, R.S., Moore, C.M.: WO2005096430 A1 (2005).

[317] Armand, M., Hammami, A., Cavalie-Kosheiry, H.: WO2005026136 A2 (2005).

[318] Choi, S.H.: US2005118494 A1 (2005).

[319] Barriere F, Ferry F, Rochefort D, Leech D. Targeting redox polymers as mediators for laccase oxygen reduction in a membrane-less biofuel cell. Electrochem Commun 2004; 6: 237-241.

[320] Sunakawa K, Sugimachi M, Inagaki M.: WO2004012811 A1 (2004).

[321] Sakai, H., Tomita, T., Takagi, R., Suzuki, Y., Hatazawa, T.: WO2004012293 A1 (2004).

[322] Kubo, W., Nomoto, T., Yano, T.: WO2006009324 A1 (2006).

[323] Farneth, W.E., Damore, M.B., Harmer, M.A.: US2005074663 A1 (2005). 
[324] Xu, X., Chen, Q., Liu, Q., Yuan, X., Ren, G.: CN1737560 A (2006).

[325] Heller, A., Mano, N., Kim, H-H., Zhang, Y., Mao, F., Chen, T., Barton, S.C.: WO2003106966 A2 (2003).

[326] DeSantis G, Jones J. Chemical modification of enzymes for enhanced functionality. Curr Op Biotechnol 1999; 10: 324-330.

[327] Torres E, Siminovich B, Barzana E, Vazquez-Duhalt R. Thermodynamic hydrophobicity of aqueous mixtures of water-miscible organic solvents predicts peroxidase activity. J Mol Catal B-Enz 1998; 4: 155-159.

[328] Brink L, Tramper J, Luyben K, Van't Riet K. Biocatalysis in organic media. Enz Microb Technol 1988 10: 736-743.

[329] Rodakiewicz-Nowak J, Kasture S.M., Dudek B, Haber J. Effect of various water-miscible solvents on enzyme activity of fungal laccases. J Mol Catal BEnz 2000; 11: 1-11.

[330] Luterek J, Gianfreda L, Wojitas-Wasilewska M, Cho N.S., Rogalski J, Jaskek H, Malarczyk E, Staszczak M, Fink-Boots M. Activity of free and immobilized extracellular Cerrena unicolor laccase in water miscible organic solvents. Holzforschung 1998; 52: 589-595.

[331] Blinkovsky, A.: US5693516 (1997).

[332] Coleman, W.J., Bylina, E.J., Youvan, D.C.: US6472163 B1 (2002).

[333] Alcalde M, Bulter T, Zumarraga M, Garcia-Arellano H, Mencia M, Plou FJ, Ballesteros A. Screening mutant libraries of fungal laccases in the presence of organic solvents. J Biomol Screen 2005; 10: 624-631. 
Table 1. Kinetic constants of laccases. The pH-values at which the constants have been measured are also included.

\begin{tabular}{|c|c|c|c|c|c|}
\hline Substrate & $\begin{array}{l}\mathbf{K}_{m} \\
(\mu \mathrm{M})\end{array}$ & $\begin{array}{l}\mathbf{k}_{\text {cat }} \\
\left(\mathbf{m i n}^{-1}\right)\end{array}$ & pH & Laccase & Reference \\
\hline \multirow[t]{20}{*}{ ABTS } & 106 & 1000 & 4.0 & Bacillus subtilis CotA & Martins et al. [44] \\
\hline & 190 & n.r.* & 6.0 & Chaetomium thermophilum & Chefetz et al. [45] \\
\hline & 23 & 1090 & 5.5 & Coprinus cinereus Lcc1 & $\begin{array}{l}\text { Schneider et al. } \\
{[24,46]}\end{array}$ \\
\hline & 41 & n.r. & 5.0 & Coprinus friesii & $\begin{array}{l}\text { Heinzkill et al. } \\
{[47]}\end{array}$ \\
\hline & 270 & 4690 & 4.5 & Melanocarpus albomyces & Kruus et al. [48] \\
\hline & 290 & 790 & 6.0 & $\begin{array}{l}\text { Myceliophthora thermophila } \\
\text { Lcc1 }\end{array}$ & Bulter et al. [49] \\
\hline & 32 & n.r. & 3.0 & Panaeolus sphinctrinus & $\begin{array}{l}\text { Heinzkill et al. } \\
\text { [47] }\end{array}$ \\
\hline & 50.6 & n.r. & 3.0 & Panaeolus papilionaceus & $\begin{array}{l}\text { Heinzkill et al. } \\
\text { [47] }\end{array}$ \\
\hline & 90 & 350000 & 3.0 & Pleurotus ostreatus POXA1 & Palmieri et al. [50] \\
\hline & 120 & n.r. & 3.0 & Pleurotus ostreatus POXA2 & Palmieri et al. [50] \\
\hline & 280 & 57000 & 3.0 & Pleurotus ostreatus POXC & Palmieri et al. [50] \\
\hline & 2500 & 74000 & 3.3 & Pleurotus sajor-caju Lac4 & Soden et al. [51] \\
\hline & 55 & n.r. & 4.0 & $\begin{array}{l}\text { Pycnoporus cinnabarinus } \\
\text { Lac1 }\end{array}$ & Record et al. [52] \\
\hline & 52 & n.r. & 5.3 & Rhizoctonia solani Lcc4 & Xu et al. [3] \\
\hline & 380 & n.r. & 4.5 & Streptomyces cyaneus & Arias et al. [53] \\
\hline & 75 & 4130 & 4.5 & Thielavia arenaria Lccl & $\begin{array}{l}\text { Paloheimo et al. } \\
\text { [54] }\end{array}$ \\
\hline & 14 & 41400 & 3.0 & Trametes pubescens LAP2 & Galhaup et al. [55] \\
\hline & 30 & 198 & 3.4 & Trametes trogii POXL3 & Garzillo et al. [56] \\
\hline & 58 & 2700 & 5.3 & Trametes villosa Lcc1 & Xu et al. [3] \\
\hline & 45 & 620 & 5.5 & Trichophyton rubrum & Jung et al. [57] \\
\hline \multirow[t]{11}{*}{ 2.6-DMP } & 100 & n.r. & 3.5 & Botrytis cinerea & $\begin{array}{l}\text { Slomczynski et al. } \\
\text { [58] }\end{array}$ \\
\hline & 96 & n.r. & 6.0 & Chaetomium thermophilum & Chefetz et al. [45] \\
\hline & 26 & n.r. & 4.5 & $\begin{array}{l}\text { Gaeumannomyces graminis } \\
\text { LAC2 }\end{array}$ & Edens et al. [59] \\
\hline & 5 & 4160 & 6.0 & Melanocarpus albomyces & Kruus et al. [48] \\
\hline & 2100 & 21000 & 5.0 & Pleurotus ostreatus POXA1 & Palmieri et al. [50] \\
\hline & 740 & n.r. & 6.5 & Pleurotus ostreatus POXA2 & Palmieri et al. [50] \\
\hline & 230 & 430 & 5.0 & Pleurotus ostreatus POXC & Palmieri et al. [50] \\
\hline & 120 & 58000 & 6.0 & Pleurotus sajor-caju Lac4 & Soden et al. [51] \\
\hline & 17 & 4030 & 6.0 & Thielavia arenaria Lccl & $\begin{array}{l}\text { Paloheimo et al. } \\
\text { [54] }\end{array}$ \\
\hline & 72 & 24000 & 3.0 & Trametes pubescens LAP2 & Galhaup et al. [55] \\
\hline & 410 & 109 & 3.4 & Trametes trogii POXL3 & Garzillo et al. [56] \\
\hline \multirow[t]{3}{*}{ Guaiacol } & 400 & n.r. & 6.0 & Chaetomium thermophilum & Chefetz et al. [45] \\
\hline & 510 & n.r. & 4.5 & $\begin{array}{l}\text { Gaeumannomyces graminis } \\
\text { LAC2 }\end{array}$ & Edens et al. [59] \\
\hline & 3100 & n.r. & 6.0 & Pleurotus ostreatus POXA2 & Palmieri et al. [50] \\
\hline
\end{tabular}




\begin{tabular}{|l|l|l|l|l|l|}
\hline & 1200 & 150 & 6.0 & Pleurotus ostreatus POXC & Palmieri et al. [50] \\
\hline & 66 & 6800 & 6.5 & Pleurotus sajor-caju Lac4 & Soden et al. [51] \\
\hline & 36 & 10800 & 3.0 & Trametes pubescens LAP2 & Galhaup et al. [55] \\
\hline & 5120 & 115 & 3.4 & Trametes trogii POXL3 & Garzillo et al. [56] \\
\hline Syringaldazine & 26 & 200 & 6.0 & Bacillus subtilis CotA & Martins et al. [44] \\
\hline & 34 & n.r. & 6.0 & $\begin{array}{l}\text { Chaetomium } \\
\text { Thermophilum }\end{array}$ & Chefetz et al. [45] \\
\hline & 26 & 180 & 5.5 & Coprinus cinereus Lcc1 & $\begin{array}{l}\text { Schneider et al. } \\
\text { [24,46] }\end{array}$ \\
\hline & 1.3 & 4710 & 6.0 & Melanocarpus albomyces & Kruus et al. [48] \\
\hline & 1.6 & 2100 & 6.0 & $\begin{array}{l}\text { Myceliophthora thermophila } \\
\text { Lcc1 }\end{array}$ & Bulter et al. [49] \\
\hline & 130 & 28000 & 6.0 & Pleurotus ostreatus POXA1 & Palmieri et al. [50] \\
\hline & 140 & n.r. & 6.0 & Pleurotus ostreatus POXA2 & Palmieri et al. [50] \\
\hline & 20 & 23000 & 6.0 & Pleurotus ostreatus POXC & Palmieri et al. [50] \\
\hline & 280 & 35000 & 6.5 & Pleurotus sajor-caju Lac4 & Soden et al. [51] \\
\hline & 28 & n.r. & 5.3 & Rhizoctonia solani Lcc4 & Xu et al. [3] \\
\hline & 4.3 & 1940 & 6.0 & Thielavia arenaria Lcc1 & $\begin{array}{l}\text { Paloheimo et al. } \\
\text { [54] }\end{array}$ \\
\hline & 6 & 16800 & 4.5 & Trametes pubescens LAP2 & Galhaup et al. [55] \\
\hline & 3.9 & 3000 & 5.3 & Trametes villosa Lcc1 & Xu et al. [3] \\
\hline
\end{tabular}

*n.r., not reported 
Table 2. Laccase production in heterologous hosts.

\begin{tabular}{|c|c|c|c|}
\hline Laccase gene & Production host & $\begin{array}{l}\text { Laccase } \\
\text { Production } \\
\left(\mathbf{m g ~ 1 ^ { - 1 } ) *}\right.\end{array}$ & Reference \\
\hline $\begin{array}{l}\text { Ceriporiopsis subvermispora } \\
\text { lcs-1 }\end{array}$ & $\begin{array}{l}\text { Aspergillus nidulans } \\
\text { Aspergillus niger }\end{array}$ & $\begin{array}{l}1.5 \\
1.5 \\
\end{array}$ & $\begin{array}{l}\text { Larrondo et al. [79] } \\
\text { Larrondo et al. [79] }\end{array}$ \\
\hline Coprinus cinereus lccl & Aspergillus oryzae & 135 & Yaver et al. [66] \\
\hline Melanocarpus albomyces lacl & Trichoderma reesei & 920 & Kiiskinen et al. [63] \\
\hline $\begin{array}{l}\text { Myceliophthora } \\
\text { thermophila lcc1 }\end{array}$ & $\begin{array}{l}\text { Aspergillus oryzae } \\
\text { Saccharomyces cerevisiae }\end{array}$ & $\begin{array}{l}19 \\
18 \\
\end{array}$ & $\begin{array}{l}\text { Berka et al. [68,69] } \\
\text { Bulter et al. [49] }\end{array}$ \\
\hline Phlebia radiata lacl & Trichoderma reesei & 20 & $\begin{array}{l}\text { Saloheimo and Niku- } \\
\text { Paavola [64] }\end{array}$ \\
\hline Pleurotus sajor-caju lac4 & Pichia pastoris & 4.9 & Soden et al. [51] \\
\hline $\begin{array}{l}\text { Pycnoporus } \\
\text { cinnabarinus lacl }\end{array}$ & $\begin{array}{l}\text { Pichia pastoris } \\
\text { Aspergillus niger } \\
\text { Aspergillus oryzae } \\
\text { Schizophyllum commune }\end{array}$ & $\begin{array}{l}8 \\
70 \\
80 \\
1200\end{array}$ & $\begin{array}{l}\text { Otterbein et al. [73] } \\
\text { Record et al. [52] } \\
\text { Sigoillot et al. [71] } \\
\text { Alves et al. [96,97] }\end{array}$ \\
\hline
\end{tabular}

* The reported production levels have been obtained in shake flask cultivation, except in the case of $P$. radiata and $M$. albomyces laccases which were produced in a laboratory fermentor. 
Table 3. Examples of laccase genes that have been shown to encode a biochemically characterized laccase protein.

\begin{tabular}{|c|c|c|c|c|}
\hline \multirow[b]{2}{*}{ Organism } & Gene & & $\begin{array}{l}\text { Protein } \\
\text { encoded } \\
\text { by the gene }\end{array}$ & \multirow[b]{2}{*}{ Reference } \\
\hline & Name & $\begin{array}{l}\text { EMBL } \\
\text { Acc.No. }\end{array}$ & $\begin{array}{l}\text { Length } \\
\text { (aa) }\end{array}$ & \\
\hline Bacillus subtilis & $\cot A$ & U51115 & 513 & Martins et al. [44] \\
\hline Botrytis cinerea & Bclcc2 & AF243855 & 581 & Schouten et al. [110] \\
\hline $\begin{array}{l}\text { Ceriporiopsis } \\
\text { subvermispora }\end{array}$ & lcs-1 & AY219235 & 519 & Karahanian et al. [111] \\
\hline Coprinus cinereus & lccl & AF118267 & 539 & $\begin{array}{l}\text { Yaver et al. [66]; } \\
\text { Schneider et al. [24] }\end{array}$ \\
\hline Cryptococcus neoformans & CNLAC1 & L22866 & 624 & Williamson [112] \\
\hline $\begin{array}{l}\text { Gaeumannomyces } \\
\text { graminis var. tritici }\end{array}$ & $L A C 2$ & AJ417686 & 577 & Edens et al. [59] \\
\hline $\begin{array}{l}\text { Marasmius quercophilus } \\
\text { (Basidiomycete C30) }\end{array}$ & lac1 & AF162785 & 517 & Dedeyan et al. [113] \\
\hline Melanocarpus albomyces & Lac 1 & AJ57169 & 623 & Kruus et al. [48] \\
\hline Myceliophthora thermophila & lccl & AR023901 & 619 & Berka et al. $[68,69]$ \\
\hline Neurospora crassa & 2 alleles & M18333-4 & 619 & Germann et al. [107] \\
\hline Phlebia radiata & lac1 & $\mathrm{X} 52134$ & 548 & Saloheimo et al. [100] \\
\hline Pleurotus ostreatus & poxalb & AJ005017 & 533 & Giardina et al. [114] \\
\hline Pleurotus ostreatus & $\begin{array}{l}\text { poxc } \\
(=\text { pox } 2)\end{array}$ & Z49075 & 533 & Giardina et al. [115] \\
\hline $\begin{array}{l}\text { Basidiomycete PM1 } \\
\text { (CECT 2971) }\end{array}$ & lac1 & Z12156 & 517 & Coll et al. [12] \\
\hline Podospora anserina & lac2 & Y08827 & 621 & $\begin{array}{l}\text { Fernandez-Larrea and } \\
\text { Stahl [104] }\end{array}$ \\
\hline Populus euramericana & $\operatorname{lac} 90$ & Y13772 & 574 & Ranocha et al. [116] \\
\hline Rhizoctonia solani & lcc4 & Z54277 & 530 & Wahleithner et al. [67] \\
\hline Streptomyces lavendulae & - & AB092576 & 631 & Suzuki et al. [89] \\
\hline Trametes pubescens & lap2 & AF414807 & 523 & Galhaup et al. [55] \\
\hline Trametes trogii & lccl & Y18012 & 496 & Garzillo et al. [56] \\
\hline Trametes versicolor & lccl & L49376 & 519 & Bourbonnais et al. [117] \\
\hline
\end{tabular}




\begin{tabular}{|l|l|l|l|l|}
\hline Trametes versicolor & $l c c 2$ & U44430 & 520 & $\begin{array}{l}\text { Cassland and } \\
\text { Jonsson [118] }\end{array}$ \\
\hline Trametes villosa & $l c c 1$ & L49377 & 520 & Yaver et al. [65] \\
\hline Trametes villosa & $l c c 2$ & AY249052 & 519 & Yaver et al. [65] \\
\hline
\end{tabular}




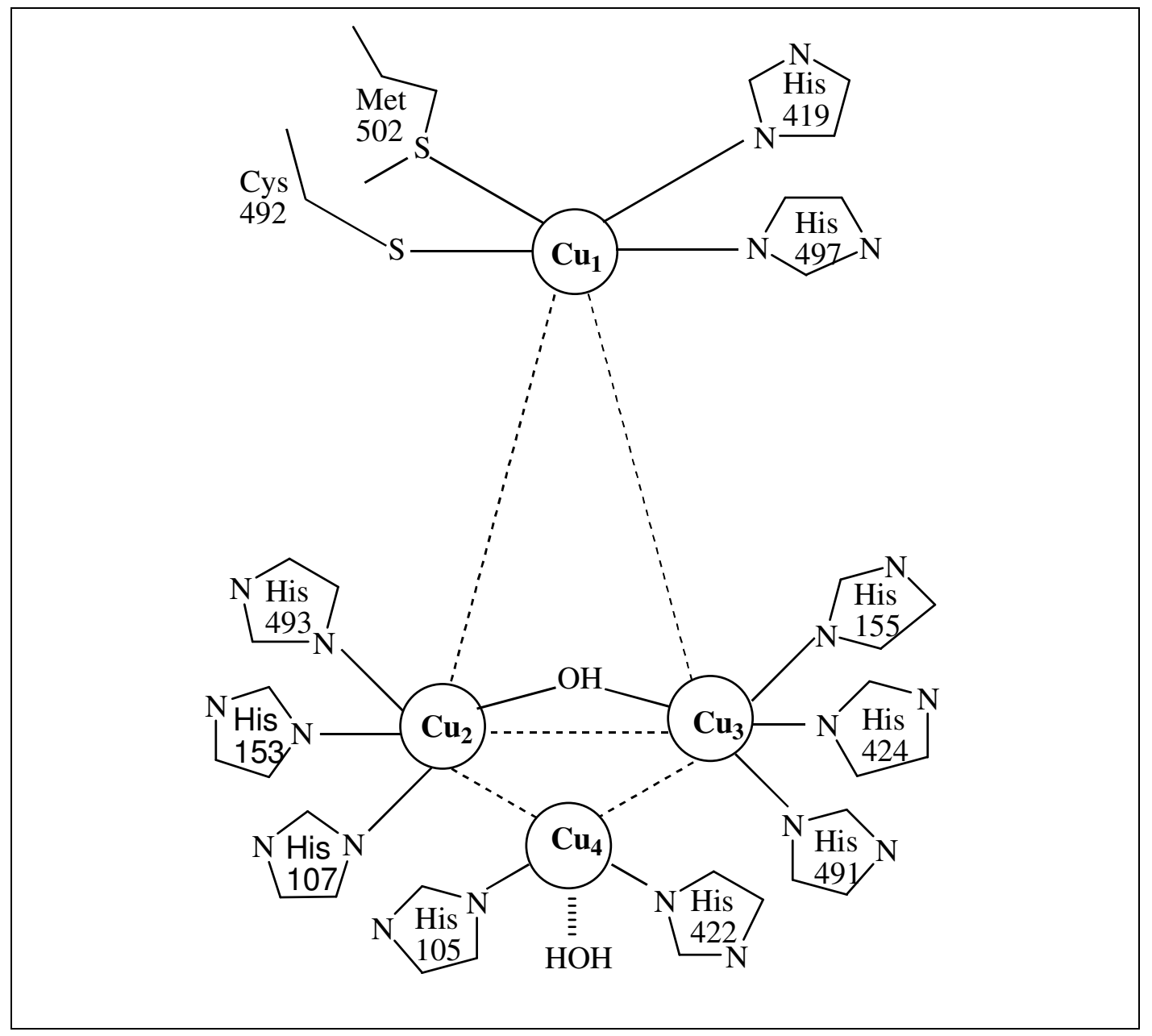

Fig. 1. Illustration of the active site of laccase showing the relative orientation of the copper atoms [31]. 


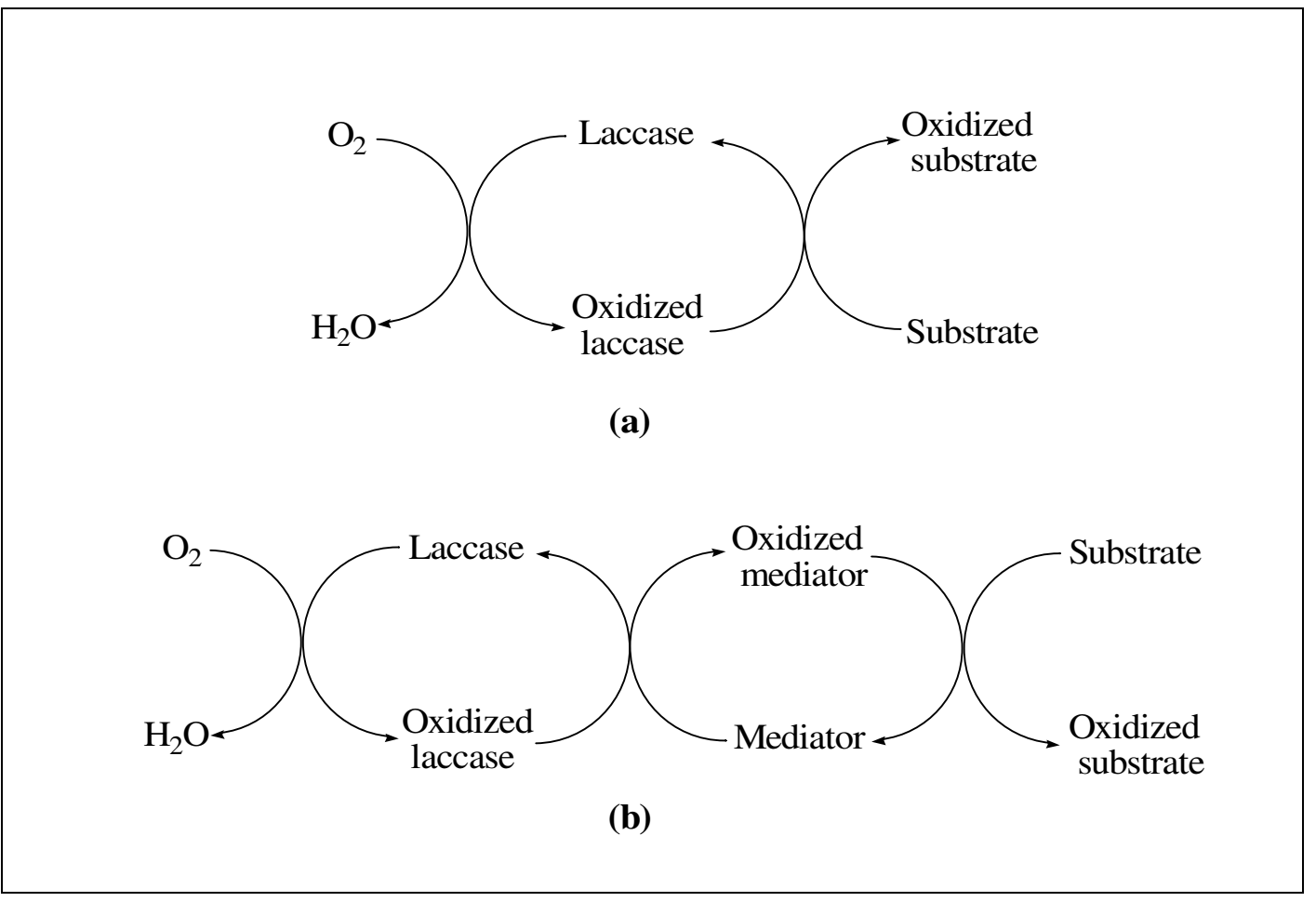

Fig. 2. Schematic representation of laccase-catalyzed redox cycles for substrates oxidation in the absence (a) or presence (b) of chemical mediators. 


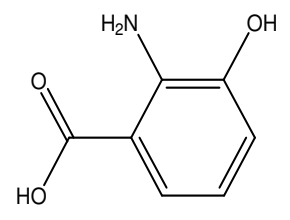

(a)

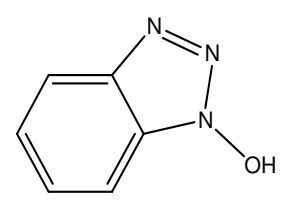

(c)

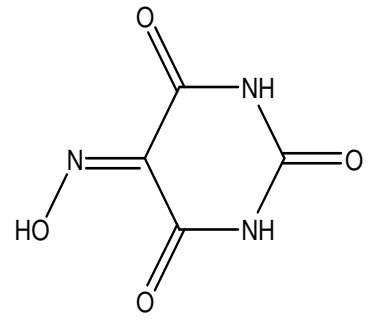

(e)

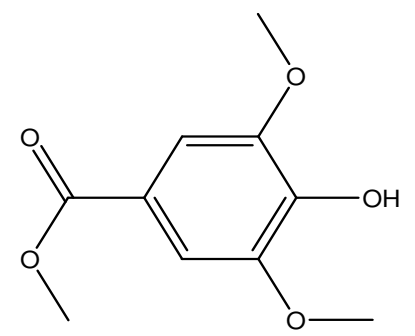

(g)<smiles>CCn1/c(=N/N=c2\sc3cc(S(=O)(=O)O)ccc3n2CC)sc2cc(S(=O)(=O)O)ccc21</smiles>

(b)<smiles>O=C1c2ccccc2C(=O)N1O</smiles>

(d)

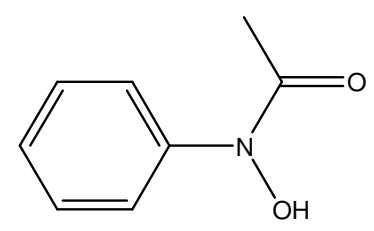

(f)



(h)

Fig. 3. Examples of laccases mediators. (a) 3-Hydroxyanthranilic acid (HAA); (b) 2,2'azino-bis-(3-ethylbenzothiazoline-6-sulphonic acid) (ABTS); (c) Nhydroxybenzotriazole (HBT); (d) $N$-hydroxyphtaimide (HPI); (e) violuric acid (VLA); (f) $\mathrm{N}$-hydroxyacetanilide (NHA); (g) methyl ester of 4-hydroxy-3,5-dimethoxy-benzoic acid (syringic acid); (h) 2,2,6,6-tetramethylpiperidine-1-yloxy (TEMPO). 


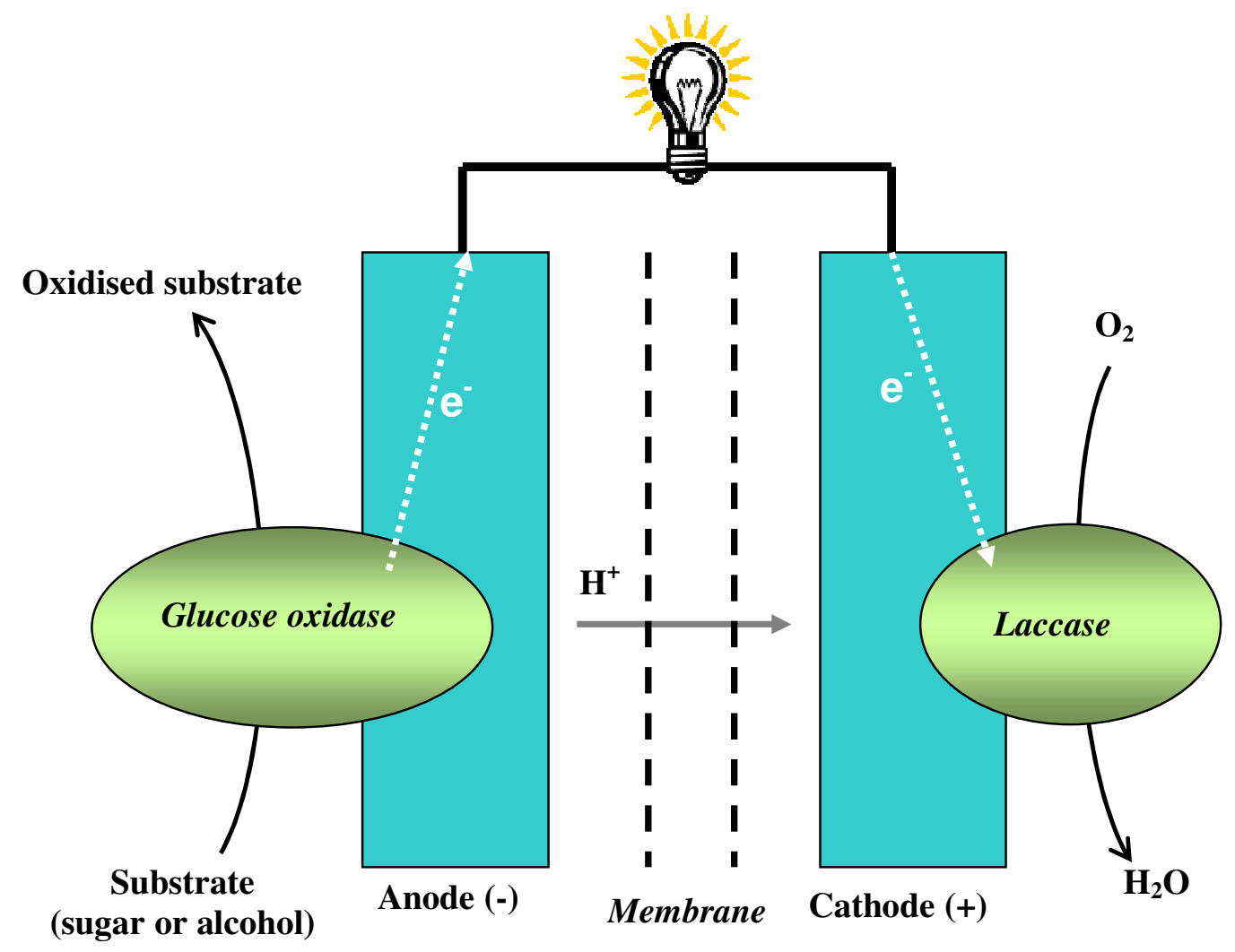

Fig. 4. Schematic representation of a biofuel cell involving glucose oxidase and laccase enzymes. 